OPEN ACCESS

Edited by:

Leonor Kremer,

Consejo Superior de Investigaciones Cientificas (CSIC), Spain

Reviewed by:

Gregory C. Ippolito, University of Texas at Austin, United States

John Löfblom,

Royal Institute of Technology, Sweden

*Correspondence: Juan C. Almagro juan.c.almagro@globalbioinc.com;

Manuel L. Penichet

penichet@mednet.ucla.edu

Specialty section: This article was submitted to Cancer Immunity and Immunotherapy, a section of the journal

Frontiers in Immunology

Received: 07 September 2017 Accepted: 24 November 2017

Published: 04 January 2018

Citation:

Almagro JC, Daniels-Wells TR, Perez-Tapia SM and Penichet ML (2018) Progress and Challenges in the Design and Clinical Development of Antibodies for Cancer Therapy.

Front. Immunol. 8:1751. doi: 10.3389/fimmu.2017.01751

\section{Progress and Challenges in the Design and Clinical Development of Antibodies for Cancer Therapy}

\author{
Juan C. Almagro ${ }^{1 *}$, Tracy R. Daniels-Wells², Sonia Mayra Perez-Tapia ${ }^{3}$ and \\ Manuel L. Penichet ${ }^{2,4,5,6,7 *}$

\begin{abstract}
GlobalBio, Inc., Cambridge, MA, United States, ${ }^{2}$ Division of Surgical Oncology, Department of Surgery, David Geffen School of Medicine, University of California, Los Angeles, Los Angeles, CA, United States, ${ }^{3}$ UDIBI, Instituto Politécnico Medicine, University of California, Los Angeles, Los Angeles, CA, United States, ${ }^{5}$ Jonsson Comprehensive Cancer Center, University of California, Los Angeles, CA, United States, ${ }^{6}$ The Molecular Biology Institute, University of California, Los Angeles, CA, United States, ${ }^{7}$ UCLA AIDS Institute, Los Angeles, CA, United States
\end{abstract} \\ Nacional, México DF, México, ${ }^{4}$ Department of Microbiology, Immunology, and Molecular Genetics, David Geffen School of
}

The remarkable progress in engineering and clinical development of therapeutic antibodies in the last 40 years, after the seminal work by Köhler and Milstein, has led to the approval by the United States Food and Drug Administration (FDA) of 21 antibodies for cancer immunotherapy. We review here these approved antibodies, with emphasis on the methods used for their discovery, engineering, and optimization for therapeutic settings. These methods include antibody engineering via chimerization and humanization of non-human antibodies, as well as selection and further optimization of fully human antibodies isolated from human antibody phage-displayed libraries and immunization of transgenic mice capable of generating human antibodies. These technology platforms have progressively led to the development of therapeutic antibodies with higher human content and, thus, less immunogenicity. We also discuss the genetic engineering approaches that have allowed isotype switching and Fc modifications to modulate effector functions and bioavailability (half-life), which together with the technologies for engineering the $\mathrm{F} v$ fragment, have been pivotal in generating more efficacious and better tolerated therapeutic antibodies to treat cancer.

Keywords: therapeutic antibodies, oncology, humanization, chimerization, phage display, Fc engineering, transgenic mice

\section{INTRODUCTION}

The hybridoma technology developed in the mid-1970s by Köhler and Milstein (1) proved to be an efficient means to isolate single specificity antibodies and produce them in unlimited amounts. This seminal achievement paved the way to effectively generate antibodies for a diverse array of therapeutic applications (2). Due to their exquisite specificity and high affinity, monoclonal antibodies have been considered particularly attractive molecules for diagnosis and/or therapy of multiple diseases, and currently antibody-based drugs represent the fastest-growing segment of all the therapeutic proteins in the biotechnology industry (3).

The first approved monoclonal antibody by the United States Food and Drug Administration (FDA) in 1985 (4) for therapeutic settings was muromonab-cluster of differentiation 3 (CD3) (Orthoclone OKT3 ${ }^{\circledR}$ ). This mouse monoclonal IgG2a antibody developed using the hybridoma 
technology, blocks CD3-mediated activation of T cells and was instrumental in the prevention of organ rejection after transplantation (5). Nonetheless, patients who were given Orthoclone $\mathrm{OKT}^{\circledR}{ }^{\circledR}$ developed a significant percentage of anti-drug antibodies, also known as a "human anti-mouse antibody" (HAMA) response (6). The HAMA response leads to the inactivation and elimination of the murine antibody (7). It also prevents the use of multiple administrations of the antibody that is required for the therapy of cancer. These issues, along with the fact that murine monoclonal antibodies can be associated with the generation of severe allergic reactions further hampered the use of antibodies of murine origin in human therapy (7).

Additionally, murine antibodies poorly interact with the human immune effector system. Relevant antibody effector functions mediated by the mouse fragment cyrstallizable $(\mathrm{Fc})$, such as antibody-dependent cell-mediated cytotoxicity (ADCC), are decreased or absent in humans (8). This also applies to the interaction with the neonatal receptor (FcRn), also known as the Brambell or "salvage receptor", which could result in a very short half-life of murine antibodies when used for human therapy (9). Hence, the multiple drawbacks of murine monoclonal antibodies as biotherapeutics in humans motivated efforts to make them more human-like molecules.

To engineer more human-like antibodies and, thus, increase efficacy while decreasing immunogenicity, non-human variable (V) domains were combined with human constant (C) domains to generate molecules with $70 \%$ or more human content. This method called chimerization was developed at the beginning of the 1980s (10) and led to the approval in 1997 of first chimeric therapeutic antibody to treat cancer, rituximab (Rituxan ${ }^{\circledR}$ ). Rituximab has been a tremendous medical and commercial success, currently being the fourth best-selling innovative drug of any kind (3).

In parallel to the clinical development and success of rituximab, other technology platforms emerged in the 1980s and 1990s aiming to generate more human-like V domains. These technology platforms have been perfected during the last three decades and include humanization (11), selection of fully human antibodies from Fv and Fab phage-displayed libraries (12), and the development of transgenic animals capable of generating fully human antibodies $(13,14)$. Moreover, the ground-breaking work on chimerization (10) also highlighted the possibility of linking any $\mathrm{V}$ fragment to diverse human $\mathrm{Fc}$ isotypes to increase or decrease cytotoxicity. Since antibody effector functions such as ADCC have been considered important mechanisms of action (MOA) for cancer immunotherapy, human IgG1 was the isotype of choice for therapeutic development of the first approved oncology therapeutic antibodies (15). More recently, other isotypes such as human IgG2 and IgG4 have increasingly been used for therapeutic development in oncology. The first human IgG2 approved in 2006 to treat cancer was panitumumab $\left(\right.$ Vectibix $\left.^{\circledR}\right)(16)$. The MOA of panitumumab mostly relies on the target blockade rather than engaging immune effector killing mechanisms such as ADCC.

Discovery and optimization platforms to generate highly specific $\mathrm{V}$ regions with a higher human content for therapeutic settings combined with Fc engineering have enabled the approval of 21 antibodies to treat cancer (Table 1). This review focuses on these antibodies, lessons learned from their engineering and clinical development, as well as challenges and prospects to generate more efficacious therapeutic antibodies. We first provide an overview of the IgG molecule, the therapeutic format of the currently approved naked antibodies. Second, we briefly review the oncology targets for which there is more than one approved therapeutic antibody. Third, we discuss the human content of the approved antibodies and the technology platforms used to engineer their $\mathrm{V}$ regions. Finally, we provide a summary of the variations of effector functions and bioavailability (half-life) of human IgG isotypes and the approaches used to modify them. Since the Fc engineering field has achieved significant progress in the last few years, beyond the development and approval of the currently marketed antibodies, we also expand on Fc variants in study and/or clinical development.

It should be noted that in addition to naked antibodies, other therapeutic modalities to treat cancer based on the antibody molecule have been gaining momentum in recent years. Such modalities include antibodies conjugated to cytotoxic organic compounds, also known as antibody-drug conjugates (ADCs) (17) as well as antibodies conjugated to radionuclides (18), protein toxins (19), and immunomodulators such as cytokines (20). Other modalities known as bispecific antibodies (21), combining two specificities in a single molecular entity, have also shown increased efficacy and/or a novel MOA when compared to the combination of the two naked antibodies binding individual targets used as the source to engineer the bispecific molecule.

In fact, the relatively recent FDA approval of three ADCs (17) and two bispecifics (21) has fueled the engineering and clinical development of these modalities. The first FDA-approved ADC was gemtuzumab ozogamicin (Mylotarg ${ }^{\mathrm{TM}}$ ) for the treatment of acute myeloid leukemia (AML). MylotargTM was voluntarily withdrawn in 2010 in the United States market but, due to the critical unmet need of treatment for patients with AML, it has recently been reintroduced in the United States with different dosing and administration schedules. The two other FDA-approved ADCs are brentuximab vedotin (Adcetris ${ }^{\circledR}$ ) and trastuzumab emtansinem (Kadcyla ${ }^{\circledR}$ ), which have proven to be highly efficacious with limited toxicity (17). The two approved bispecific antibodies are catumaxomab (Removab ${ }^{\circledR}$ ) and blinatumomab (Blincyto ${ }^{\circledR}$ ). These antibody-based drugs have shown to be a breakthrough in the field of cancer immunotherapy. Both bispecifics bind CD3 on T-cells with one arm of the molecule. With the other arm, catumaxomab and blinatumomab bind cancer cells expressing epithelial cell adhesion molecule (EpCAM) or cluster of differentiation 19 (CD19), respectively. Simultaneous binding of CD3 and EpCAM or CD19 bring in the close proximity cancer cells with T-cells leading to a specific and highly efficacious killing process of the cancer cells (21). Although ADC and bispecific modalities are not reviewed here due to the vast amount of information published in this field, compounded with space limitations, it should be highlighted that the methods for discovery and optimization of $\mathrm{V}$ regions and modifications of the Fc to tailor the effector functions to a given MOA, are common and can be applied to all antibody-based modalities. 
TABLE 1 | United States FDA-approved therapeutic antibodies to treat cancer as of July 30, 2017.

\begin{tabular}{|c|c|c|c|c|c|c|c|}
\hline $\begin{array}{l}\text { International } \\
\text { non-proprietary } \\
\text { names (INN) }\end{array}$ & $\begin{array}{l}\text { Commercial } \\
\text { name }\end{array}$ & Company & $\begin{array}{l}\text { Approval } \\
\text { date }\end{array}$ & Type & Isotype & Target & Indication \\
\hline Rituximab & Rituxan ${ }^{\otimes}$ & Genentech & $11 / 26 / 1997$ & Chimeric & $\lg G 1$ & CD20 & B-cell non-Hodgkin lymphoma \\
\hline Trastuzumab & Herceptin $^{\circledR}$ & Genentech & 9/25/1998 & Humanized & $\lg G 1$ & HER2 & Metastatic breast cancer \\
\hline Alemtuzumab & Campath ${ }^{\circledR}$ & Genzyme & $5 / 7 / 2001$ & Humanized & $\lg$ 1 1 & CD52 & B-cell chronic lymphocytic leukemia \\
\hline Cetuximab & Erbitux $^{\circledR}$ & ImClone Systems & 2/12/2004 & Chimeric & $\lg G 1$ & EGFR & Metastatic colorectal carcinoma \\
\hline Bevacizumab & Avastin $^{\circledR}$ & Genentech & 2/26/2004 & Humanized & $\operatorname{lgG} 1$ & VEGF & Metastatic colorectal cancer \\
\hline Panitumumab & Vectibix ${ }^{\circledast}$ & Amgen & $9 / 27 / 2006$ & Fully human & $\lg G 2$ & EGFR & Metastatic colorectal cancer \\
\hline Ofatumumab & Arzerra ${ }^{\circledR}$ & Glaxo Grp & 10/26/2009 & Fully human & $\lg G 1$ & CD20 & Chronic lymphocytic leukemia \\
\hline Ipilimumab & Yervoy ${ }^{\circledR}$ & Bristol-Myers Squibb & $3 / 25 / 2011$ & Fully human & $\lg G 1$ & CTLA-4 & Metastatic melanoma \\
\hline Pertuzumab & Perjeta $^{\circledR}$ & Genentech & 6/8/2012 & Humanized & $\lg G 1$ & HER2 & Metastatic breast cancer \\
\hline Obinutuzumab & Gazyva $^{\circledR}$ & Genentech & $11 / 1 / 2013$ & Humanized & $\lg$ G1 & CD20 & Chronic lymphocytic leukemia \\
\hline Ramucirumab & Cyramza $^{\circledR}$ & Eli Lilly & $4 / 21 / 2014$ & Fully human & $\lg G 1$ & VEGFR2 & Gastric cancer \\
\hline Pembrolizumab & Keytruda $^{\circledast}$ & Merck & 9/4/2014 & Humanized & $\lg G 4$ & PD-1 & Metastatic melanoma \\
\hline Nivolumab & Opdivo ${ }^{\circledR}$ & Bristol-Myers Squibb & $12 / 22 / 2014$ & Fully human & lgG4 & PD-1 & Metastatic melanoma \\
\hline Dinutuximab & Unituxin ${ }^{\circledast}$ & United Therapeutics & 3/10/2015 & Chimeric & $\lg G 1$ & GD2 & Pediatric high-risk neuroblastoma \\
\hline Daratumumab & Darzalex ${ }^{\circledast}$ & Janssen Biotech & $11 / 16 / 2015$ & Fully human & $\lg$ lg1 & CD38 & Multiple myeloma \\
\hline Necitumumab & Portrazza ${ }^{\circledR}$ & Eli Lilly & $11 / 24 / 2015$ & Fully human & $\lg G 1$ & EGFR & Metastatic squamous non-small cell lung carcinoma \\
\hline Elotuzumab & Empliciti® & Bristol-Myers Squibb & $11 / 30 / 2015$ & Humanized & $\lg G 1$ & SLAMF7 & Multiple myeloma \\
\hline Atezolizumab & Tecentriq $^{\circledR}$ & Genentech & $5 / 18 / 2016$ & Humanized & $\lg$ G1 & PD-L1 & Bladder cancer \\
\hline Olaratumab & Lartruvo ${ }^{\circledR}$ & Eli Lilly & 10/19/2016 & Fully human & $\lg$ I1 & PDGFRA & Soft tissue sarcoma \\
\hline Avelumab & Bavencio ${ }^{\circledR}$ & EMD Serono & 3/23/2017 & Fully human & $\lg G 1$ & PD-L1 & Metastatic Merkel cell carcinoma \\
\hline Durvalumab & Imfinzi® $^{\circledast}$ & AstraZeneca & $5 / 1 / 2017$ & Fully human & $\lg G 1$ & PD-L1 & Urothelial carcinoma \\
\hline
\end{tabular}

The table was generated by parsing the information on approved antibodies compiled by The Antibody Society (http://www.antibodysociety.org/news/approved-antibodies/), CenterWash (http://www.centerwatch.com/drug-information/fda-approved-drugs/), and contrasted with recent reviews on the state of the art in therapeutic antibodies for treatment of cancer cited in this review. The antibodies are listed chronologically in the table in the order of approval date. The INN are highlighted in bold in the Table and text of the article.

\section{THE IgG MOLECULE}

Five different antibody classes exist in humans, determined by the nature of the $\mathrm{C}$ regions of the heavy chain (HC). These classes are designated by lower-case Greek letters: $\gamma$ for IgG; $\delta$ for IgD; $\varepsilon$ for IgE; $\alpha$ for IgA, and $\mu$ for $\operatorname{IgM}$ (22). The IgG is the most prevalent class of antibodies in blood and the most common molecular format used as therapeutic. Figure $\mathbf{1}$ shows that the IgG is assembled with two identical HCs and two identical light chains (LCs), classified in two types, $\kappa$ and $\lambda$. The LC has a single variable $\left(\mathrm{V}_{\mathrm{L}}\right)$ domain and a single constant $\left(\mathrm{C}_{\mathrm{L}}\right)$ domain, whereas, the $\mathrm{HC}$ consists of a single variable $\left(\mathrm{V}_{\mathrm{H}}\right)$ domain, a hinge region, and three constant $\left(\mathrm{C}_{\mathrm{H}} 1, \mathrm{C}_{\mathrm{H}} 2\right.$, and $\left.\mathrm{C}_{\mathrm{H}} 3\right)$ domains. The $\mathrm{C}_{\mathrm{H}} 3$ domain is located at the C-terminus of the IgG. In the $\mathrm{N}$-terminus, the pairing of the $\mathrm{LC}$ and the Fd fragment $\left(\mathrm{V}_{\mathrm{H}}\right.$ and $\mathrm{C}_{\mathrm{H}} 1$ ) from the $\mathrm{HC}$ forms the fragment antigen binding (Fab), where the antigen-binding site is located. The heterotetrameric structure of IgG is held together covalently by disulfide bonds between the $\mathrm{C}_{\mathrm{L}}$ and $\mathrm{C}_{\mathrm{H}} 1$ domains and between the hinge (interdomain) region of the two $\mathrm{HCs}$.

The diversity of the antigen-binding site, and hence the capacity of antibodies to bind virtually any target, comes from diverse germline gene repertoires (24). The IGLV and IGLJ germline genes encode the $\mathrm{V}_{\mathrm{L}}$ domain, whereas the $\mathrm{V}_{\mathrm{H}}$ domain is encoded by the repertoires of IGHV, IGHD, and IGHJ germline genes (25). Additional amino acid variation in the antigen-binding site occurs through somatic mechanisms, such as somatic hypermutation in humans and mice, and gene conversion in other species such as chickens and rabbits $(26,27)$.

The germline and somatic amino acid variability is concentrated in the complementarity-determining regions (CDRs).
Three CDRs in $\mathrm{V}_{\mathrm{L}}$ : CDR-L1, CDR-L2, and CDR-L3, and three in $\mathrm{V}_{\mathrm{H}}$ : CDR-H1, CDR-H2, and CDR-H3, alternate with conserved regions called framework regions (FRs), four in $\mathrm{V}_{\mathrm{L}}$ : FR-L1, FR-L2, FR-L3, and FR-L4, and four in $\mathrm{V}_{\mathrm{H}}$ : FR-H1, FR-H2, FR-H3, and FR-H4. The six CDRs are brought together by folding and noncovalent association of the V domains in the Fv (Figure 1) at the tip of the Fabs.

Two Fabs are linked to one $\mathrm{Fc}_{\mathrm{c}}$ via the hinge region that provides flexibility to the antibody molecule to interact with diverse configurations of the targets. The $\mathrm{Fc}$ is formed by the non-covalent association of $\mathrm{C}_{\mathrm{H}} 2$ and $\mathrm{C}_{\mathrm{H}} 3$ domains, with critical residues in the hinge and $\mathrm{C}_{\mathrm{H}} 2$ determining the immune effector functions of the IgG antibody via interaction with the Fc gamma family of receptors ( $\mathrm{Fc} \gamma \mathrm{Rs}$ ) and the complement component C1q. Engagement of Fc $\gamma$ Rs on immune effector cells activates cellular responses such as ADCC and antibody-dependent cell-mediated phagocytosis (ADCP). Complement fixation, starting with the interaction of the antibody and the complement component C1q, induces activation and formation of the membrane attack complex (MAC), finally resulting in complement-mediated cytotoxicity (CDC).

The human IgG has four subclasses: IgG1, IgG2, IgG3, and IgG4, also known as isotypes (28). These isotypes have evolved different Fc sequences with differential capacity to elicit effector functions (Table 2). Isotype-specific engagement of such immune functions is based on selective Fc receptor interactions on distinct immune cell populations such as natural killer (NK) cells, neutrophils, and macrophages, as well as the ability to bind $\mathrm{Clq}$, an initial protein in the complement pathway leading to a "cascade" of events that results in the formation of the MAC and the induction of tumor cell killing. 


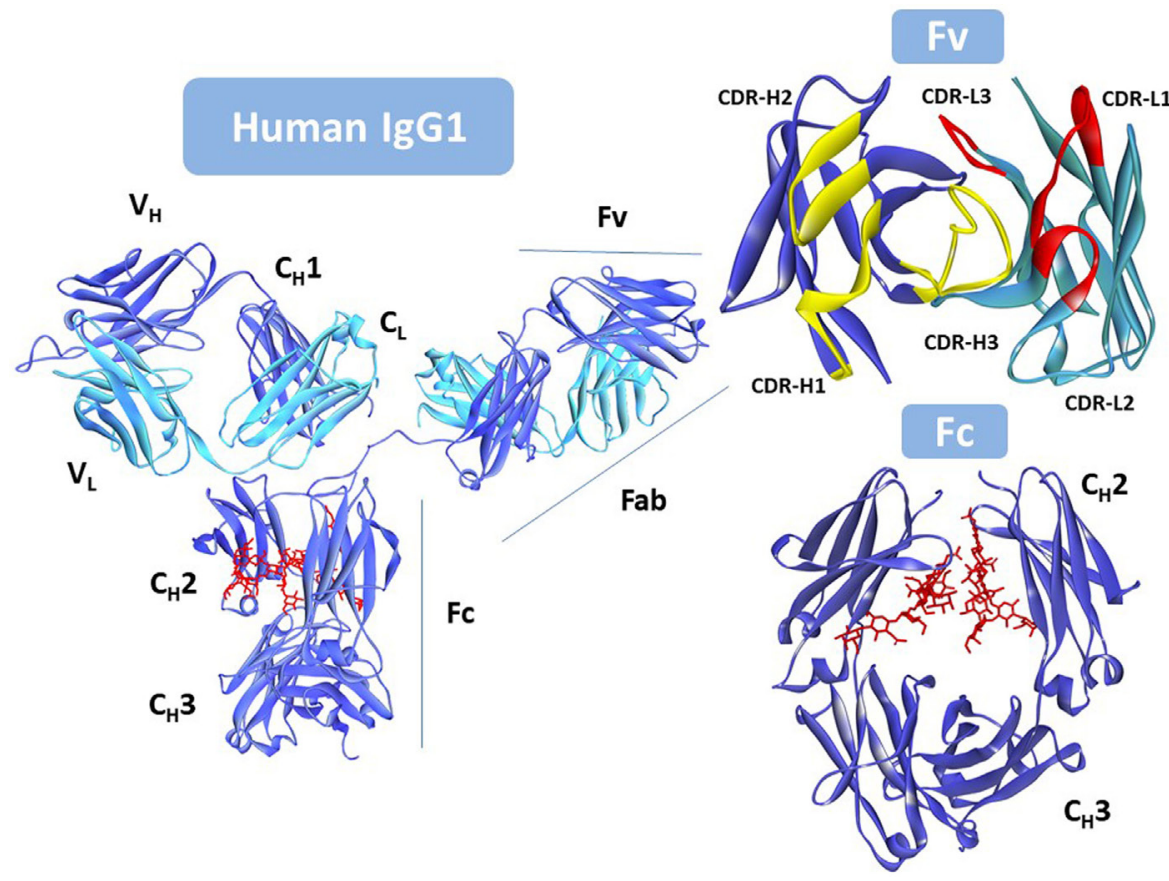

FIGURE 1 | Intact human IgG1, Protein Data Bank (PDB) ID: 1HZH (23). Heavy chain is shown in blue. Light chain in cyan, and the N-glycan in red. Fv (top right) with the antigen-binding site seen from the antigen perspective. $V_{L}$ complementarity-determining regions (CDRs) in yellow; $V_{H} C D R s$ in red. $F_{C}$ (bottom right) rotated with respect to the antibody to better show the location of the $\mathrm{N}$-glycan (in red). Notice that one of the hinge peptides is missing in the figure. Due to its flexibility it was not solved since coordinates for this region are not available in the PDB file. This figure was generated using Discovery Studio.

Additionally, IgG antibodies contain an $\mathrm{N}$-glycosylation site at asparagine-297 (N297) in the $\mathrm{C}_{\mathrm{H}} 2$ domain. Modification of this $N$-linked glycan affects the Fc-mediated effector functions. Furthermore, specific residues located near the $\mathrm{C}_{\mathrm{H}} 2-\mathrm{C}_{\mathrm{H}} 3$ junction engage the major histocompatibility complex (MHC) class I related receptor, known as the FcRn that largely determines the blood half-life of antibodies.

\section{THERAPEUTIC ANTIBODIES APPROVED FOR THE TREATMENT OF CANCER}

The current FDA-approved antibodies to treat cancer (Table 1) target 13 molecules including membrane proteins such as cluster differentiation 20 (CD20) and epidermal growth factor receptor (EGFR), soluble protein ligands for instance vascular endothelial growth factor (VEGF), and a disialoganglioside (GD2). These antibodies aim at different MOAs (Figure 2), which result from an interplay of the biology of the target, affinity of the antibody for the target, and/or effector functions such as ADCC, ADCP, and/ or CDC that are elicited. The MOAs may also include blockade of oncogenic pathways with inhibition of malignant cell proliferation and/or induction of apoptosis, blockade of the formation of new blood vessels, and enhancement of the antitumor cytotoxic $\mathrm{T}$ cell (CTL) immune response to target tumor cells by inhibiting the immune cell checkpoint resulting in their activation.

The most relevant targets in terms of number of approved therapeutic antibodies are CD20, EGFR, its paralog human EGFR2 (HER2), and programmed cell death protein 1 (PD-1)
TABLE 2 | Functional properties of the human IgG isotypes.

\begin{tabular}{lcccc}
\hline Properties & IgG1 & IgG2 & IgG3 & IgG4 \\
\hline Approximate molecular weight $(\mathrm{kDa})$ & 146 & 146 & 165 & 146 \\
Hinge length (number of amino acids) & 15 & 12 & 62 & 12 \\
Antibody-dependent cell-mediated cytotoxicity & +++ & $+/--$ & ++ & $+/--$ \\
Antibody-dependent cell-mediated phagocytosis & + & + & + & $+/--$ \\
C1q binding & + & $+/-$ & +++ & - \\
Complement-mediated cytotoxicity & ++ & $+/-$ & ++ & - \\
FcRn binding & + & + & $+/-$ & + \\
Plasma half-life (days) & 21 & 21 & $5-7.5$ & 21 \\
Approximate average plasma concentration & 9 & 3 & 1 & 0.5
\end{tabular}
( $\mathrm{mg} \mathrm{ml}^{-1}$ )

Adapted from Strohl and Strohl (29) and Bruggemann et al. (30).

and its ligand 1 (PD-L1). A brief description of these targets and the interaction with the therapeutic antibodies follows. A recent review on the above targets, other targets, and their interaction with therapeutic antibodies and MOAs has been published (31).

\section{Anti-CD20 Antibodies}

Targeting CD20 with antibodies led to the approval of rituximab back in 1997, the first therapeutic antibody approved to treat cancer. CD20 is highly expressed on B cells throughout their development, but is absent on the hematopoietic stem cell (32). Although the physiological function of CD20 remains unclear, several lines of evidence suggest a role for CD20 in calcium signaling of B-cell antigen receptor activation. It has also been suggested that CD20 exists predominantly as a tetramer on the cell surface. CD20 is not shed or internalized upon antibody binding, which facilitate 


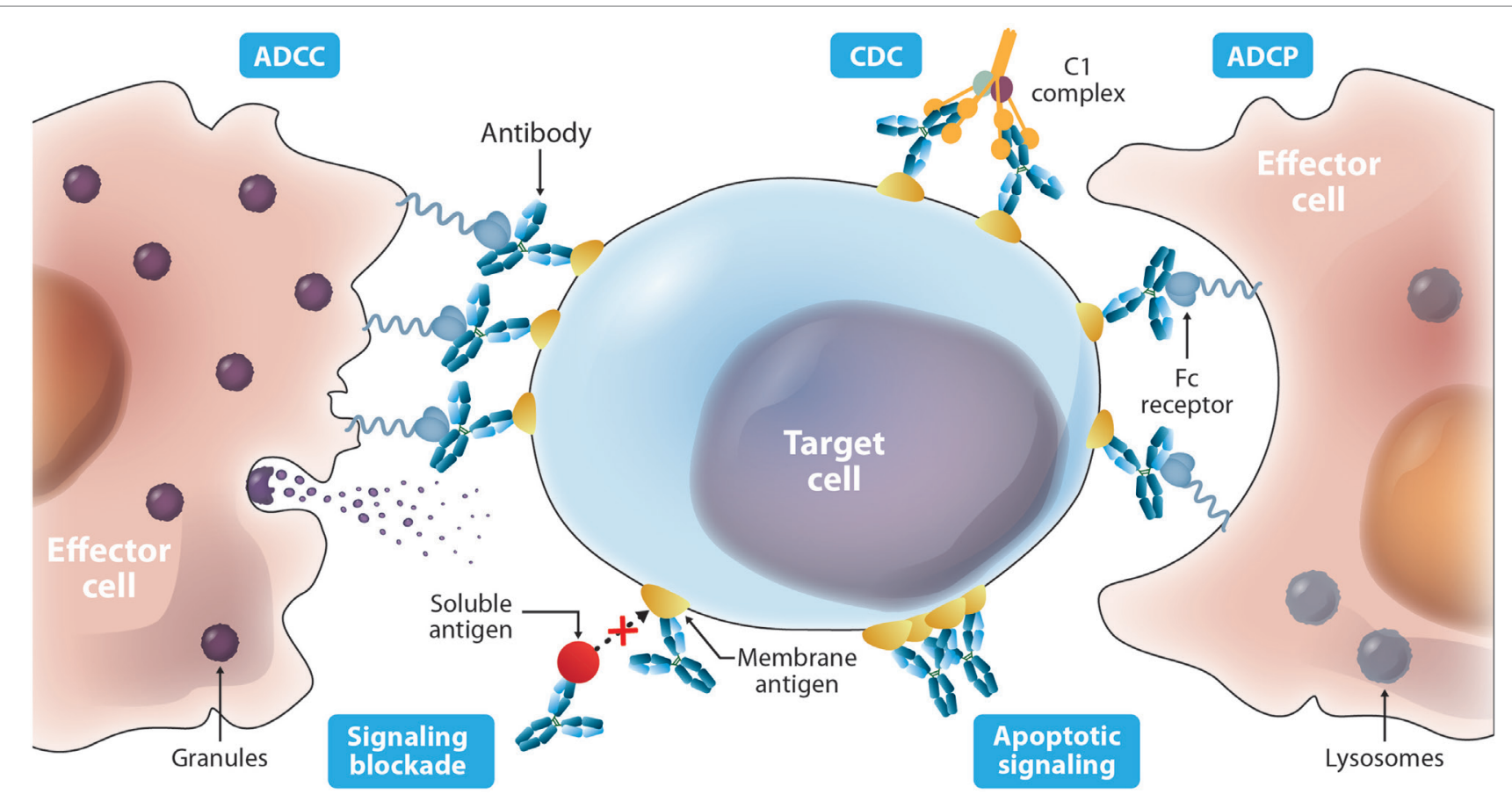

FIGURE 2 | Diverse mechanisms of actions described for antibody-based drugs. Antibodies such as lgG1 can activate immune effector functions such as antibody-dependent cell-mediated cytotoxicity (ADCC), antibody-dependent cell-mediated phagocytosis (ADCP), and complement-mediated cytotoxicity (CDC) via specific binding to membrane targets on the cancer cell and binding to the Fc receptors on the surface of effector cells. Antibodies can also elicit protective activity by targeting a soluble ligand or their receptors on the surface of cancer cells blocking their interaction. In addition, targeting a cell surface receptor may trigger events that result in cytotoxic activity independent of blocking its ligand, such as receptor dysfunction due to cross-linking.

the recruitment of immune effector cells and mediate sustained immunologic activity as relevant MOA (33).

CD20 has four transmembrane domains with two extracellular loops, one large loop of 45 amino acids, and a short loop of nine residues. Anti-CD20 antibodies are classified as Type I or Type II according to their interaction with CD20 and primary MOA (32). Rituximab and ofatumumab are Type I antibodies, whereas obinutuzumab is a Type II. Among other characteristics, Type I antibodies have full binding capacity, high $\mathrm{CDC}$, and moderate direct cell death induction. Type II antibodies have half binding capacity, low CDC, and stronger direct cell death induction.

Peptide scanning and mutagenesis studies have shown that rituximab binds the large CD20 loop (34). Although obinutuzumab is a Type II antibody, its epitope overlaps with that of rituximab, but is shifted toward the C-terminus of the large CD20 loop. X-ray crystallography (35) of the extracellular large loop in complex with rituximab or obinutuzumab Fabs have confirmed that while these antibodies bind partially overlapping epitopes, they differ in their interaction with the large CD20 loop.

Ofatumumab is a Type I antibody like rituximab but binds the small CD20 extracellular loop (32). Binding of ofatumumab seems to influence the large loop conformation but does not interact with the critical residues of CD20 determining the epitope of obinutuzumab and rituximab. The differences in primary MOA of ofatumumab, obinutuzumab, and rituximab suggest that in addition to the different epitopes they bind, other factors such as orientation of the antibodies when bound to CD20 are important in their therapeutic efficacy (32).

\section{Anti-EGFR Antibodies}

EGFR and HER2 were among the first receptors to be identified and associated with human tumors $(36,37)$. Physiologically, EGFR (also known as HER1/ErbB1) and the EGFRs 2, 3, and 4 (HER2/ErbB2, also known as the neu oncogene, HER3/ErbB3, and HER4/ErbB3) are involved in cell growth control and differentiation. Several crystal structures of EGFR and HER2 and complexes with therapeutic antibodies are now available (38). The extracellular domain (ECD) of EGFR is composed of four domains I-IV, which are arranged in two conformations: an "extended" active form and the alternative inactive form, which is folded over or "tethered." In the inactive form, domain II interacts with domain IV, while domains I and III are far apart. The active extended dimeric form is induced by the ligand, epidermal growth factor (EGF), in which domains I and III are closer together.

All three approved anti-EGFR therapeutic antibodies bind domain III and block the interaction with EGF. The X-ray crystal structures of necitumumab and cetuximab Fabs in complex with EGFR indicate that these antibodies bind a very similar surface on EGFR but, having different CDRs, do so through a set of different interactions (39). In fact, necitumumab was isolated from a human antibody phage-display library by competition with cetixumab. The similarity in the epitopes of necitumumab and cetuximab suggested that the former would have similar properties to the chimeric antibody cetuximab, but with the benefits of a fully human antibody (39). 
The epitope recognized by panitumumab also overlaps with cetuximab (40). However, screening of peptide phage-display libraries and mutagenesis studies have shown that although these antibodies bind overlapping regions on EGFR, some amino acids in the epitope are critical for cetuximab binding, whereas others are specific for panitumumab. The relevance of these specific interactions in clinical settings emerged from studies in a patient with colorectal cancer who acquired a point mutation under treatment with cetuximab and developed resistance to treatment with this antibody, whereas treatment with panitumumab was still effective in this patient (41). This mutation seemed to abrogate cetuximab binding to the mutated EGFR, while panitumumab binding remained unaffected. Thus, differences in the functional epitopes of panitumumab and cetuximab could have clinical relevance as they may be instrumental in the selection of patients and decisions regarding their treatment.

\section{Anti-HER2 Antibodies}

The structure of HER2 is similar to that of EGFR (42), but HER2 does not bind a ligand, functioning primarily via heterodimerization with ligand-bound partners of the EGFR family, mostly HER3. Comparison of several X-ray crystal structures (38) indicate that HER2 ECD adopts an extended conformation due to two non-conservative key mutations in the domain IV residues, which replace glycine 563 (G563) and histidine 565 (H565) in EGFR by proline (P) and phenylalanine (F) in HER2. These mutations prevent the contacts of domain II-IV, rendering in HER2 the extended active conformation seen in EGFR but without ligand binding in HER2. Moreover, HER2 ECD does not homodimerize in solution, perhaps due to conformational differences between the extended ECD module of HER2 and the EGFR dimeric conformation (38).

Trastuzumab binds domain IV, close to the membrane, and its MOA involves disruption of HER2 homodimerization and prevention of cleavage of the ECD, which leads to the active truncated receptor p95HER2 (43). This truncated form of HER2 maintains kinase activity and can migrate to the nucleus to act as oncogenic nuclear factor. Pertuzumab binds domain II and prevents heterodimerization of HER2 with HER3 and EGFR, blocking growth of HER2-amplified breast cancer (44). Of note, the combination of pertuzumab and trastuzumab in breast cancer therapy has been shown to be more efficacious than the treatment with the single therapeutics (45).

\section{Anti-PD-1/PD-L1 Antibodies}

Programmed cell death protein 1 (PD-1) and its ligand (PD-L1) are immune checkpoints that inhibit CTL activity $(46,47)$. PD-L1 is constitutively expressed on a subset of macrophages, but may be rapidly upregulated in different tissue types and by tumors in response to interferon-gamma (IFN- $\gamma$ ) and other inflammatory mediators. Importantly, many cancer cells express $\mathrm{PD}-\mathrm{L} 1$ as a mechanism of immune evasion. Thus, targeting PD-1 and PD-L1 with antibodies has demonstrated significant therapeutic benefits in clinical trials, especially resulting in activation of the antitumor CTL response, a phenomenon known as immune checkpoint blockade (48).
The structure of PD-L1 in complex with PD-1 has been extensively studied (49). Several X-ray crystal structures are now available, including human PD-L1 alone, mouse PD-1 complexed with human PD-L1, and human PD-1 complexed with human PD-L1 or antibodies. These structures have shown that pembrolizumab and nivolumab epitopes on PD-1 overlap with part of the PD-L1 binding site. The affinity of these antibodies for PD-1 is in the low picomolar range (50). This is several orders of magnitude stronger than the affinity of PD-L1 for PD-1, estimated in the nanomolar range (51), which suggests that the MOA of pembrolizumab and nivolumab is through outcompeting PD-L1 for binding to PD-1. Furthermore, pembrolizumab and nivolumab have been engineered with IgG4 isotypes, which has an important influence in their MOA by reducing toxicity of these antibodies. IgG4 lacks effector functions, such as ADCC and CDC, which may be potentially harmful to the immune cells expressing PD-1 when targeting this ligand with antibodies.

On the PD-L1 side, atezolizumab, durvalumab, and avelumab bind distinct epitopes but all interfere with PD-1 binding (52), preventing the PD-L1/PD-1 interaction. These three checkpoint inhibitors are of the IgG1 class, but the Fcs of atezolizumab and durvalumab have been modified to eliminate antibody effector functions. Atezolizumab is an aglycosylated antibody, whereas durvalumab is a Fc-modified triple mutant variant. Avelumab is reported to be a non-modified IgG1. Therefore, like with the anti-PD-1 therapeutic antibodies, the MOA of atezolizumab, durvalumab, and avelumab is an interplay between affinity, epitope, and Fc variants.

\section{IMMUNOGENICITY AND HUMAN CONTENT}

Immunological reactions to biotherapetics involve a complex combination of diverse components not fully yet understood, including product-, disease- and patient-specific factors (53). The lack of standardization in the terminology and approaches used for collecting, analyzing, and presenting immunogenicity data also makes it difficult to find a consensus on immunogenicity results (54).

Nonetheless, pioneering work on the specificity of the immune reactions to peptides (55), prior to determining the amino acid sequence of a protein or its three-dimensional (3D) structure, suggested that the phylogenetic distance between two species is an important factor in eliciting antibodies. Subsequent determination of the amino acid sequence of the first proteins in the early 1960s indicated that the phylogenetic distance between two species is imprinted in the amino acid sequences (56). These differences play a key role in launching specific immune responses against non-self proteins. In fact, diverse in silico predictive methods to assess potential immunogenic spots based on the amino acid sequence have been developed and are part of the toolbox used to engineer therapeutic proteins (57). Thus, engineering antibodies with lower immunogenicity has been driven in part by generating amino acid sequences that are as human as possible.

The diversity of antibodies comes from the recombination of diverse germline gene repertoires (25) and somatic mutations generated during the hypermutation process (26). Since 
the somatic mutations are specific to an immune response and some mutations may be immunogenic in other individuals with a different immunological history and background, it can be assumed that the ideal human antibody from an immunogenicity standpoint should be identical to the genes encoded by the germline repertoire.

The physical maps of the human IGH and IGL genes loci were elucidated in the 1990s, together with an initial estimation of number and germline gene sequences encoding the functional human antibodies $(25,58-60)$. In the last two decades, more human germline genes from diverse populations have been sequenced and studied. More recently, the application of next-generation sequencing methods to the study the antibody repertoires from diverse individuals have led to the characterization of an increasing number of alleles $(61,62)$. This information is compiled and curated at the international ImMunoGeneTics information system $\left(\mathrm{IMGT}^{\circledR}\right)^{1}$, with alleles " 01 ” representing the oldest germline genes. The " 01 " alleles have also been identified in several individuals, thus, perhaps representing the most common human antibody germline genes.

Figure 3 shows a comparison of the percentage of identities of the $\mathrm{V}_{\mathrm{H}}$ and $\mathrm{V}_{\mathrm{L}}$ regions of the antibodies listed in Table 1 with respect to the closest match in the repertoire of human antibody germline genes compiled at the IMGT. Both $\mathrm{V}_{\mathrm{H}}$ and $\mathrm{V}_{\mathrm{L}}$ of the chimeric antibodies have an average around $70 \%$ identities with respect to the human germlines, also defined as human content. Chimeric antibodies have a wider variation in the percentage of identities with respect to the human germline genes as well. Humanized antibodies reach an average $85 \%$, whereas, fully human antibodies show $90 \%$ or more human content.

${ }^{1} \mathrm{http}: / /$ www.imgt.org.

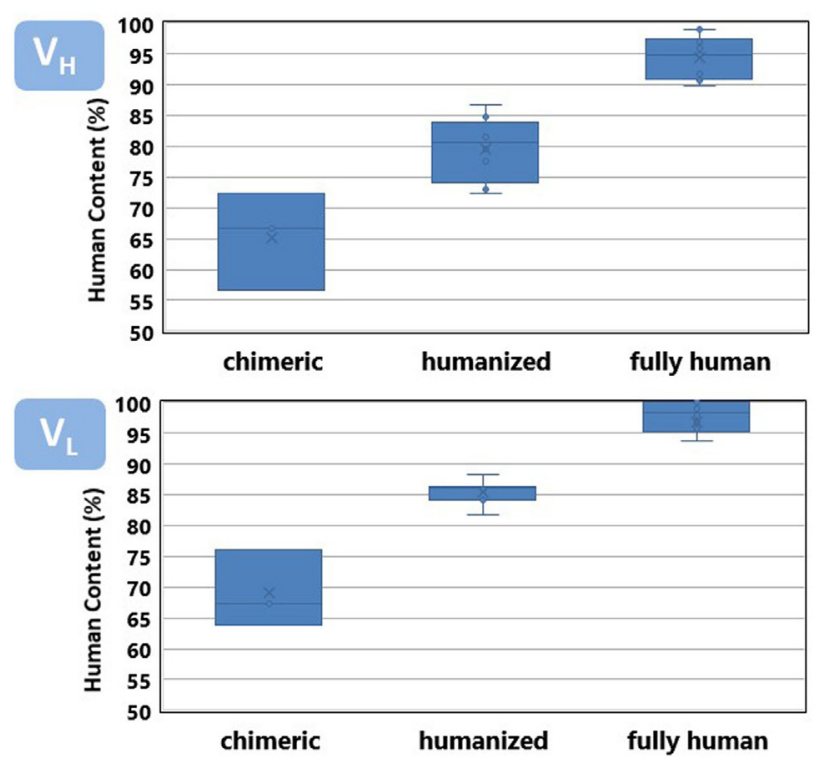

FIGURE 3 | Human content of chimeric, humanized, and fully human antibodies listed in Table 1. See Figure $\mathbf{4}$ caption for a detailed description of the human content calculation.
Overall, the $\mathrm{V}_{\mathrm{H}}$ region has a slightly less human content than $\mathrm{V}_{\mathrm{L}}$. $\mathrm{V}_{\mathrm{H}}$ leads the interaction of the antibody with its specific target and tends to accumulate more somatic mutations (24), diverging faster from the germline configuration. It poses a higher challenge for antibody engineers to increase the human content of the therapeutic antibodies while preserving the specificity and affinity of the parental, non-human antibody.

The departure from $100 \%$ human content observed in fully human antibodies roughly corresponds with the frequency of somatic mutations observed in the antibody human sequences studied by several research groups (63-65). It has been reported that mutations in $\mathrm{V}_{\mathrm{H}}$ and $\mathrm{V}_{\mathrm{L}}$ follows an exponential distribution, with as much as $15-20 \%$ of the $\mathrm{V}$ regions showing no mutations at the amino acid level. Following these sequences in the germline gene configuration, fewer and fewer sequences have an incremental number of mutations. The average number of somatic mutations per human $\mathrm{V}$ region observed in diverse samples of sequences product of immune responses has been estimated in around eight and five mutations for $\mathrm{V}_{\mathrm{H}}$ and $\mathrm{V}_{\mathrm{L}}$, respectively.

The placement of mutations with respect to the closest germline gene match is shown in Figure 4. Chimeric antibodies show amino acid differences all along the $\mathrm{V}$ regions, with a high number of non-human residues in the FR-3 of $\mathrm{V}_{\mathrm{H}}$ and FR-1 of $\mathrm{V}_{\mathrm{L}}$. In contrast, the mutations of the humanized antibodies are mostly clustered in the CDRs. Fully human antibodies show very few mutations, with some $\mathrm{V}$ regions being in the germline configuration.

\section{Chimeric Antibodies}

After the FDA approval of rituximab, two additional chimeric antibodies, cetuximab and dinutuximab, reached the market for oncology indications. Cetuximab was generated by immunizing mice with purified EGFR and replacing the mouse constant domains of the mouse antibody 225 with those of human IgG1. The chimeric molecule, named C225, showed around five-fold higher affinity and increased tumor growth reduction than the parental mouse antibody (70). Dinutuximab was developed from a murine antibody specific for GD2 (71). The chimeric molecule (ch14.18), also a human IgG1, showed identical binding as the murine IgG2a antibody but, the ADCC was 50-fold to 100 -fold higher than the parental mouse antibody when using human effector cells (72). Therefore, in addition to rendering less immunogenic molecules, chimerization overcame some of the drawbacks of the early murine monoclonal antibodies by generating therapeutic molecules with the same or improved affinity than the parental mouse antibodies but with enhanced effector functions.

\section{Humanized Antibodies}

Although chimeric antibodies were more efficacious and less immunogenic than mouse antibodies, they still elicited a "human anti-chimeric antibody" (HACA) response (73). Thus, to further increase the human content of therapeutic antibodies, in the second half of the 1980s Winter's group at the Medical Research Council (11) showed that by grafting the CDRs from an antibody into FRs of another antibody, the specificity and affinity of CDR donor antibody can be transferred to the antibody providing 


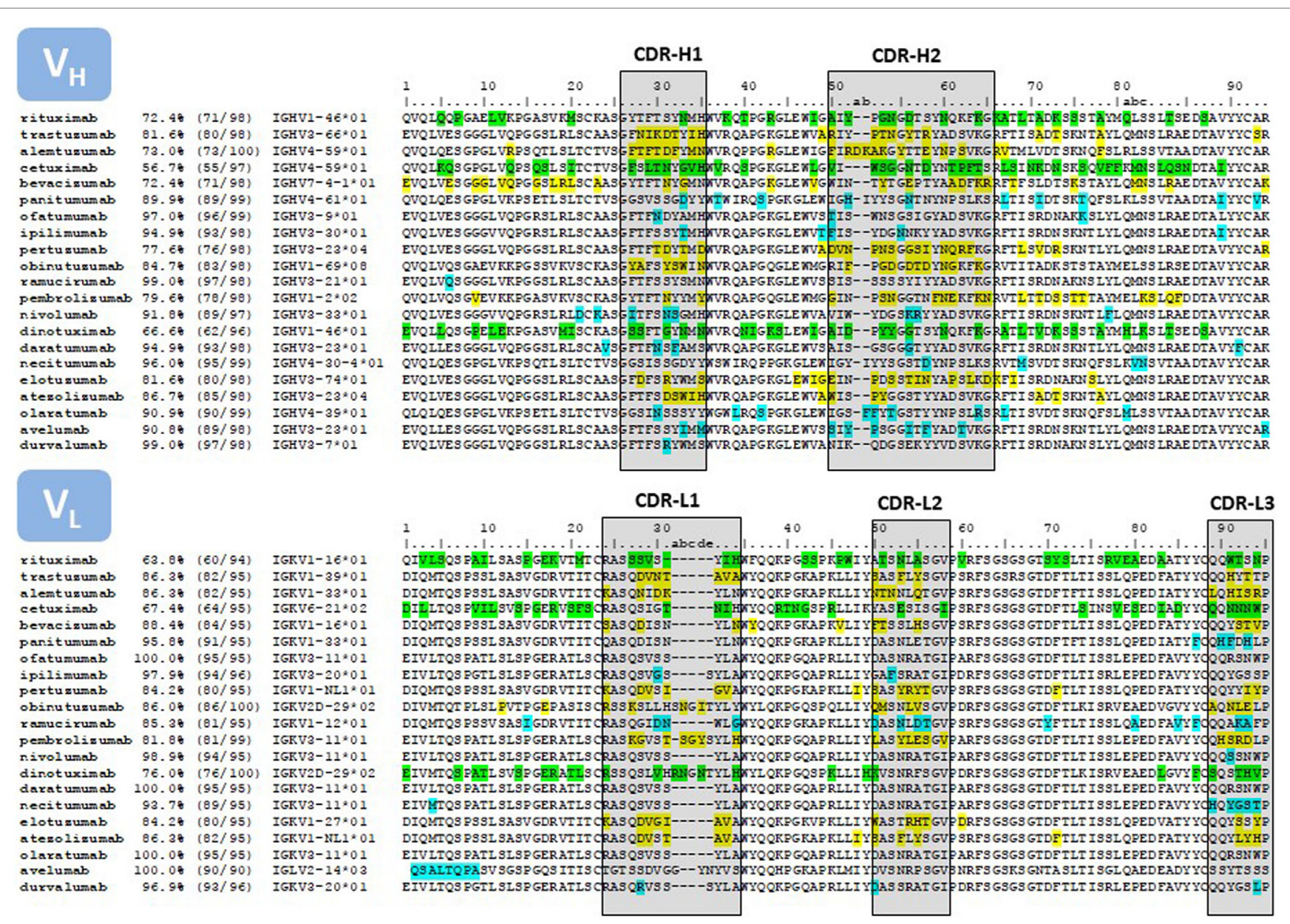

FIGURE 4 | Sequence alignment of the V regions of the antibodies listed in Table 1. Only the amino acids encoded in the IGHV and IGKV genes are reported. The amino acid sequences were taken from DrugBank (66). In those cases where more than one sequence per therapeutic antibody is reported at DrugBank or no sequence was available in this source, we used the sequences compiled by Jain and collaborators (67). The sequences were compared with the repertoire of human germlines compiled at IMGT using IgBLAST (https://www.ncbi.nlm.nih.gov/igblast/) and the percentage of identities as reported in IgBLAST's output is listed in the second column of the Figure. The third column lists the number of identities divided the length of the amino acid sequence. Some antibodies, in particular the sequence of the chimeric antibodies, matched more than one human germline gene sequence with equal percentage of identities. In these cases, we report the first germline gene in the IgBLAST's output. In other instances, the antibody sequence matched more than one human germline gene allele with equal number of identities, but with amino acid mismatches at different positions of the $V$ region. In these cases we report the "01" allele. The numbering on top of the sequences corresponds with Chothia's definition (68). CDRs are delimited with boxes, following Kabat's definition (69), except at the CDR-H1, which is a combination of Chothia's and Kabat's definition. The color code corresponds to mismatches with respect to the closest human germline gene; green, chimeric antibodies; yellow, humanized antibodies; blue, fully human antibodies.

the FRs. It was first applied to engineer alemtuzumab (74). The parental antibody was a rat IgG2a, called YTH 34.5HL. Its CDRs were grafted into the human $\mathrm{V}_{\mathrm{H}}$ and $\mathrm{V}_{\mathrm{L}}$ FRs of the known antibody structures at the time NEW (75) and REI (76), respectively.

In an alternative approach, Queen and collaborators (77) at Protein Design Labs (PDL) humanized daclizumab (Zenapax $\left.{ }^{\circledR}\right)-$ not discussed here as it has no indication in cancer. Daclizumab was humanized by CDR grafting, but the human FRs were selected by maximizing homology between the murine antibody sequence providing the CDRs and the human antibody donating the FRs. In addition, a computer model of the mouse antibody, guided the identification of several murine amino acids in the FRs that interacted with the CDRs or antigen and back mutated those amino acids into the CDR-grafted antibody, thus, improving binding of the final product. Together with the successful humanization of alemtuzumab by Winter's group, these pioneering works laid the foundations for humanization via CDR grafting, the humanization method used to engineer all of the humanized antibodies listed in Table 1.

For instance, Carter and collaborators (78) humanized the murine antibody mumAb4D5, which had potential for human therapy due to its anti-proliferative (cytostatic) effect against human breast and ovarian cancer cell lines overexpressing HER2. The CDRs of mumAb4D5 were grafted in consensus human FRs and several mouse residues were incorporated into the FR aiming to retain the affinity of the parental mumAb4D5 antibody. One of the humanized versions of this antibody named humAb4D5-8, later named trastuzumab, showed a four-fold increase in HER2 
binding affinity compared to the parental mumAb4D5, similar cytostatic activity, and more efficient ADCC against HER2 overexpressing cancer cells. Thus, this study demonstrated that humanization technologies can be helpful not only to increase the human content of Fv region but also to enhance the binding properties of the antibody and its therapeutic efficacy.

Bevacizumab (79) and pertuzumab (80) were engineered using a similar method. The other humanized antibodies for oncology indications, e.g., pembrolizumab, atezolizumab, obinutuzumab, and elotuzumab have also been obtained by grafting non-human CDRs into human FRs, with designed backmutations, which replace human residues by the original mouse residues in the FR to stabilize the CDR conformations and, hence, preserve or improve the affinity of the parental non-human antibody. The number of backmutations varies depending on the source of the FR, namely: mature antibodies (77), consensus FRs (78) and more recently the use of human germline genes $(81,82)$. The FR selection method, sequence similarity between the parental non-human donor and human acceptor sequences, as well as the affinity for the target are all contributing factors to obtaining humanizing antibodies with higher human content (83).

Although humanized antibodies have more human content than chimeric antibodies they still do not eliminate the possibility of the induction of a "human anti-human antibody" (HAHA) response (84). However, humanization is still broadly used due in part to the accessibility of hybridoma technology to academic laboratories and small biotech companies. Also, the relatively recent expiration of the dominant humanization patents $(85,86)$ and diversification of humanization methods (83) have contributed to the widespread use of the technology.

While the HAMA response can in principle be directed against the entire antibody and the HACA response against the $\mathrm{V}$ regions, the HAHA response is even more focused against the CDRs (see Figure 4). Thus, replacing non-human amino acids in the CDRs with human amino acids has been undertaken by several companies such as Xencor (87), Facet Biotech Corporation (88), and more recently Pfizer $(89,90)$. For instance, Townsend and collaborators (89) generated libraries of binary substitutions at the CDRs by combining the parental non-human residues with human germline residues at each position and screened the libraries for clones with restored antigen-binding capacity. The resulting antibodies increased the human content by $17-29 \%$, rendering molecules indistinguishable from fully human antibodies. Apgar and collaborators (90) followed a rational approach based on the structure of the antigen-antibody complex and were able to replace 11 out of 26 non-human residues in the CDRs. Thus, it could be expected that due to the accessibility and low cost of the hybridoma technology and commoditization of CDR grafting compounded with CDR humanization rendering antibodies indistinguishable from fully human antibodies, humanized antibodies with a higher human content will reach clinical development in the near future.

\section{Fully Human Antibodies}

Fully human therapeutic antibodies emerged in the 1990s with the development of two technology platforms: human antibody Fv or Fab phage-display libraries (12) and transgenic animals bearing the human antibody repertoire (14). Eleven antibodies listed in Table $\mathbf{1}$ have been discovered using these platforms. Of note, only three: necitumumab, ramucirumab, avelumab were obtained using phage display. Although phage display was developed prior to transgenic animals, the latter requires less optimization and thus shorter timelines to reach clinical development (91). In addition, since enriching technologies such as phage display are based on in vitro selection, the antibody fragments coming out of the selection and screening processes do not undergo the in vivo selection process and tend to carry developability liabilities (discussed below).

Two transgenic mice produced the fully human antibodies approved for oncology indications, e.g., Medarex (14) and Abgenix (16). The first therapeutic antibody developed by one of these platforms was panitumumab. This therapeutic antibody was obtained using the XenoMouse ${ }^{\circledR}$ (92). Durvalumab was discovered using the same platform (93), whereas, the other five antibodies listed in Table 1 were discovered using the Medarex technology. Interestingly, four of the Medarex antibodies share the same $V_{L}, I G K V 3-11^{\star} 01$, with three of them in the germline gene configuration and one (nivolumab) with only one mutation at the CDR-L3 (Figure 4). Although the Medarex mouse has only a small fraction of the complete human $\mathrm{V}_{\mathrm{H}}$ and $\mathrm{V}_{\mathrm{L}}$ repertoires, it demonstrated that even with limited diversity, the plasticity of $V_{L}$ to pair with diverse $\mathrm{V}_{\mathrm{H}}$ chains can generate specific and high affinity therapeutic antibodies against unrelated targets. Other transgenic mice have been developed in the last three years including the Kymouse (94) and the Trianni mouse (95). These platforms rely on more diverse repertoires of human antibody genes, which enable the selection of highly diverse human antibodies and circumvent some of the limitations of the early transgenic mice.

Despite the success of transgenic mice as a source of therapeutic antibodies, immunization does not always lead to antibodies with the desired antibody affinity and specificity $(96,97)$. This is particularly true for conserved epitopes between human and mouse orthologs. Transgenic rats (98) and more recently chickens (OmniChicken) (99) may partially mitigate this limitation. Nonetheless, toxic targets and selection of proteins with specific active conformations in environments of interest for a given MOA are not well suited for an immunization approach and require an alternative solution for antibody discovery.

Phage display opened the possibility of designing and manipulating the repertoire of antibody genes to be used as source of antibodies (24), thus, leading to selection of fully antibodies in vitro. Since the discovery process via phage display is performed in vitro one can also choose the optimal conditions to select for desired biophysical and biochemical properties, target pre-defined epitopes locked in specific conformations, avoid immunodominant epitopes by masking them with other known antibodies and/or focus the selection of rare or cross-reactive epitopes.

For instance, ramucirumab was developed starting from three antibodies with identical $\mathrm{V}_{\mathrm{H}}$ sequence isolated from de Haard and collaborators' Fab display library (100). These antibodies bound specifically the VEGF receptor 2 (VEGFR2), blocked the VEGF/KDR interaction, and inhibited VEGF-induced proliferation of human endothelial cells and migration of KDR leukemia 
cells. A new library was built by combining the single $\mathrm{V}_{\mathrm{H}}$ with a repertoire of naïve $V_{L}$ chains, and diverse and specific $V_{L}$ chains for VEGFR2 were selected. Then, a consensus $V_{H}: V_{L}$ pair, termed 1121 , was identified after selection tailoring the stringency of the panning conditions to obtain picomolar binders (101).

Necitumumab was also isolated from de Haard and collaborators' library by using A431 carcinoma cells, which express high levels of EGFR. Competition with cetuximab for binding to the cell surface generated one clone, termed $11 \mathrm{~F} 8$, which displayed a dose-dependent inhibitory effect on EGF-stimulated EGFR activation in A431 cells. A comparison of the structures of Fab11F8 with the Fab derived from cetuximab (FabC225) both in complex with EGFR, indicated that the epitope of the two Fabs was remarkably similar, but the antibodies having different CDRs, bound EGFR through a set of different interactions (39). Necitumumab, the new fully human antibody was thus developed, had similar biological properties to cetuximab, but without the disadvantages of a chimeric antibody.

Until relatively recently, phage display technology was controlled by a few companies, holding their technology patents (102). These patents expired in Europe and the United States, thus, allowing the free use of the antibody discovery methodology via phage display by academic laboratories and small biotech organizations. As phage display technology has become a commodity, several companies such as BioRad using $\mathrm{HuCAL}^{\circledR}$ (103), Distributed Bio via SuperHuman synthetic libraries, ${ }^{2}$ and GlobalBio/ADL by means of semi-synthetic ALTHEA Gold Libraries $^{\mathrm{TM}^{3}}$ are licensing phage display libraries and/or offering discovery services at a relatively low cost without royalty payments.

In addition to phage, other display platforms have been developed, including ribosome (104), bacteria (105), yeast (106), and mammalian (107) display. Each of these platforms has advantages and disadvantages. One of the advantages of yeast display, which is the most commonly used, over phage display is the screening using fluorescence-activated cell sorting. This advantage has proven to be an efficient means to isolate antibodies with very high affinity, e.g., in the low femtomolar range (108). In addition, while phage is limited to the display of antibody fragments such as scFvs or Fabs, yeast enables the display of full IgG antibodies with glycosylation. Since the end therapeutic product is commonly an IgG and its efficacy and toxicity are an interplay between target epitope, affinity, Fc isotype and/or variants and glycosylation, yeast display has become a suitable platform for efficient therapeutic discovery and development (109).

\section{DEVELOPABILITY}

As more antibodies have reached the market, and more importantly, many failed to perform in preclinical development and clinical trials, the term "developability" emerged in the 2010s (110, 111). Developability encompasses a set of design principles and experimental methods to assess the potential of

${ }^{2}$ http://www.distributedbio.com

${ }^{3}$ http://www.globalbioinc.com/Services/ antibodies to be further developed or manufactured, formulated, and stabilized to achieve the desired therapeutic effect. For instance, post-translational amino acid modifications such as deamidation of asparagine $(\mathrm{N})$, oxidation of methionine $(\mathrm{M})$, and isomerization of aspartic acid, have been identified as potential developability liabilities (112). Modifications of these amino acids can lead to heterogenicities in the drug and/or lack of potency if these amino acids are involved in the interaction with the target. Other amino acids such as tryptophan (W) can induce aggregation and, thus, immunogenicity or lack of solubility at concentrations required for the therapeutic indication, which impairs the further development of the product. Hence, identification of these amino acids and removal when possible during the early discovery process are now part of the antibody engineering process to increase the success rate of preclinical and clinical development.

On the experimental side, recently Jain and collaborators (67) have assessed the limits of developability of 137 FDA-approved therapeutic antibodies (including those listed in Table 1) as well as those in advanced stages of clinical development, i.e., clinical phase I, II, and III. More favorable biophysical properties were found in approved antibodies. Hence, the biopharma industry has progressively been implementing experimental assessment of biophysical properties in early stages of the discovery campaign to progress molecules that would perform well in preclinical development. This is particularly important for therapeutic antibodies generated via phage display, related enriching technologies, and humanized antibodies where the selection process proceed in vitro without the filters imposed in vivo that tend to select well-behaved molecules when used as therapeutics.

\section{MODULATING FC-DEPENDENT EFFECTOR FUNCTIONS}

As reviewed above, choosing the right IgG isotype is key to achieve the desired MOA. All antibodies compiled in Table 1 are IgG1 except three: panitumumab, nivolumab, and pembrolizumab. The human IgG1 elicits strong effector functions such as ADCC and CDC (Table 2), which have been shown to be an important mechanism to kill cancer cells and has been broadly used in development of anticancer antibodies. However, the importance of the other IgG isotypes such as IgG2 and IgG4, as well as mutations of the Fc region (Table 3 ) have had a significant impact in the success of cancer-targeting antibodies, and are now an essential part of designing and testing therapeutic antibodies. The current approved Fc-engineered antibodies and further developments in the field of Fc engineering are reviewed in the following sections.

\section{Human IgG Isotypes and Mutations to Alter Effector Functions}

ADCC occurs when an antibody simultaneously binds its cognate antigen on the surface of the malignant cell and the Fc region of the antibody binds activating Fc gamma receptors $(\mathrm{Fc} \gamma \mathrm{R})$ on the surface of an effector cell. This stimulates a signaling cascade 
TABLE 3 | Examples of human Fc mutations for functional modification.

\begin{tabular}{|c|c|c|c|c|c|}
\hline Function & Effect & Class & Application & Mutations or changes & Reference \\
\hline \multirow[t]{17}{*}{ ADCC } & Enhanced & $\lg G 1$ & Cancer & S298A/E333A/K334A & $(113,114)$ \\
\hline & & & & S239D/I332E & $(114,115)$ \\
\hline & & & & S239D/A330L/I332E & $(114,116,117)$ \\
\hline & & & & S298A & (113) \\
\hline & & & & $\mathrm{D} 280 \mathrm{H}$ & $(118)$ \\
\hline & & & & K290S & (118) \\
\hline & & & & F243L/R292P/Y300L & (119) \\
\hline & & & & F243L/R292P/Y300L/N305I/P396L & (119) \\
\hline & Diminished & $\lg$ G1 & Cancer & G236A & $(120)$ \\
\hline & & & Cancer & K326W/E333S & $(121)$ \\
\hline & & & RA & C130S/C136S/C139S/P148S & $(122)$ \\
\hline & & & Cancer & C226S/C229S/E233P/L234V/L235A & (123) \\
\hline & & & Cancer & S298N, S298V, or S298D & $(118)$ \\
\hline & & & Cancer & D265A & $(113)$ \\
\hline & & & ID, RA, Cancer & M252Y/S254T/T256E & $(124)$ \\
\hline & & $\lg G 3$ & Cancer & L234A/L235A/P329S & $(125)$ \\
\hline & & $\lg \mathrm{G} 4$ & Cancer & L235A/G237A/E318A & $(126)$ \\
\hline \multirow[t]{4}{*}{ ADCP } & Enhanced & $\lg G 1$ & Cancer & G236A & $(120)$ \\
\hline & & & & $\mathrm{S} 239 \mathrm{D} / \mathrm{I332E}$ & $(114)$ \\
\hline & & & & S239D/A330L/I332E & $(114)$ \\
\hline & Diminished & $\lg G 1$ & Cancer & C226S/C229S/E233P/L234V/L235A & $(123)$ \\
\hline \multirow[t]{19}{*}{ CDC } & Enhanced & $\lg G 1$ & Cancer & K326W & $(121)$ \\
\hline & & & & E333S & $(121)$ \\
\hline & & & & T256N/A378V/N434Y ${ }^{\mathrm{a}}$ & (127) \\
\hline & & & & T256N/A378V/S383N/N434Ya & $(127)$ \\
\hline & & & & P228LI/T256N/A378V/N434Ya & $(127)$ \\
\hline & & & & P230S/N315D/M428L/N434Ya & $(127)$ \\
\hline & & & & K320E/Q386R & $(128)$ \\
\hline & & $\lg G 2$ & Cancer & K326W/E333S & $(121)$ \\
\hline & Diminished & $\lg G 1$ & Cancer & S239D/A330L/I332E & $(114)$ \\
\hline & & & & C226S/C229S/E233P/L234V/L235A & (123) \\
\hline & & & & D270A & (129) \\
\hline & & & & K322A & $(129)$ \\
\hline & & & & P329A & (129) \\
\hline & & & & P331A & $(129)$ \\
\hline & & & & T307A/N315D/A330V/E382V/N389T/N434Y & $(127)$ \\
\hline & & & & N315D/A330V/N361D/A378V/N434Y & $(127)$ \\
\hline & & & & E294Del/T307P/N434Yc & $(127)$ \\
\hline & & & & M252Y/S254T/T256E & $(127)$ \\
\hline & & $\lg G 3$ & Cancer & P329S & $(125)$ \\
\hline \multirow[t]{18}{*}{ Half-life } & Increased & $\lg G 1$ & ID, RA, Cancer & M252Y/S254T/T256E & $(124)$ \\
\hline & & & ID & T250Q/M428L & (130) \\
\hline & & & Cancer, AID & N434A & $(131,132)$ \\
\hline & & & & L235A/G237A/E318A & $(126)$ \\
\hline & & & Cancer & T307A/E380A/N434A & $(131)$ \\
\hline & & & Cancer & M428L/N434S & (133) \\
\hline & & & Cancer & T307A/N315D/A330V/E382V/N389T/N434Y & $(134)$ \\
\hline & & & & T256N/A378V/N343Y & (134) \\
\hline & & & & N315D/A330V/N361D/A378V/N434Y & (134) \\
\hline & & & & V259I/N315D/434Y & $(134)$ \\
\hline & & & & P230S/N315D/M428L/N343Y & (134) \\
\hline & & & & E294Del/T307P/N434Yc & $(134)$ \\
\hline & & $\lg G 2$ & Not disclosed & T250Q/M428L & $(130)$ \\
\hline & & $\operatorname{lgG3}$ & ID & $\mathrm{R} 435 \mathrm{H}$ & $(135)$ \\
\hline & Decreased & $\lg G 1$ & Cancer, AID & I253A & (131) \\
\hline & & & & P257I/N434H & (136) \\
\hline & & & Not disclosed & P257I/Q311I & (136) \\
\hline & & & & D376V/N434H & (136) \\
\hline
\end{tabular}

a Produced in YB2/0 cells to yield afucosylated antibodies to enhance ADCC.

${ }^{b}$ This construct also includes the T299L mutation that leads to an aglycosylated antibody with reduced ADCC activity.

${ }^{\circ}$ E294Del: residue 294 is deleted in this construct.

AID, autoimmune disease; ID, infectious diseases; RA, rheumatoid arthritis.

EU numbering is used in all cases. 
within the effector cell that results in the release of cytotoxic granules (see Figure 2) that kill the targeted tumor cell. The activating FcyRs are the high affinity FcyRI (CD64) that is expressed on immune cells such as macrophages, neutrophils, and dendritic cells; the intermediate affinity Fc $\gamma$ RIIa (CD32a) that is expressed on macrophages, neutrophils, and Langerhans cells; and the low-affinity FcyRIIIa (CD16a) that is expressed on NK cells, macrophages, and neutrophils (137).

ADCC has been shown to play an important role in the efficacy of many antibodies that target cell surface proteins for cancer therapy $(138,139)$, especially through the interaction with the FcyRIIIa receptor. The allotype (158V) of F $\gamma$ RIIIa binds IgG with a higher affinity and shows increased ADCC activity compared to the low-affinity allotype (158F) (140). For instance, a correlation exists between the clinical efficacy of rituximab, trastuzumab, and cetuximab administered to cancer patients with a homozygous allotype 158V (141-144). $\mathrm{ADCP}$ is a similar effector function that results in phagocytosis instead of the release of granules from the effector cell. Effector cells that are capable of phagocytosis, such as macrophages, can mediate both ADCP and ADCC against targeted tumor cells (145). Increasing the ability of a therapeutic antibody to elicit ADCC and ADCP is advantageous in many applications for cancer therapy where ADCC and ADCP are known to play important roles in eliminating the tumor. An IgG1 named $3 \mathrm{~F} 2-3 \mathrm{M}$ that is specific for the receptor tyrosine kinase EphA2 and contains three mutations (S239D/A330L/I332E) in the Fc domains demonstrated enhanced ADCC activity against a panel of three EphA2-expressing malignant cells regardless of the Fc $\gamma$ RIIIa allotype of the peripheral blood mononuclear cells that were used as effector cells (116). No ADCC was observed against a malignant cell line not expressing EpHA2. These same mutations in a trastuzumab variant showed increased ADCC compared to wild-type trastuzumab irrespective of HER2 expression levels and Fc $\gamma$ RIIIa allotype (114). A different triple mutant S298A/E333A/K334A of trastuzumab showed similar effects (113). These studies are important because they suggest that these mutant antibodies can be used effectively in all patients, not just those with certain allotypes. Furthermore, the S239D/A330L/I332E triple mutant of trastuzumab and rituximab also showed enhanced ADCP (114).

$\mathrm{CDC}$ is initiated when the $\mathrm{Fc}$ region of an antibody bound to a cancer cell binds the $\mathrm{C} 1 \mathrm{q}$ protein, which triggers a cascade of events that culminates in the formation of the MAC that forms transmembrane channels in the cell membrane of the malignant cell leading to cell death. CDC has also been shown to be a mechanism of action of some therapeutic antibodies $(138,139)$. In these cases, $\mathrm{Fc}$ engineering to enhance the $\mathrm{CDC}$ activity of an antibody can be advantageous. For example, rituximab with single mutations (K326W or E333S) has shown increased CDC (121). It is important to note that an increase in CDC was not always observed with mutations of K326 to other amino acids besides tryptophan $(\mathrm{W})$. This serves as a cautionary note that the amino acid substitution can be critical and should be considered carefully.

For antibodies targeting checkpoint inhibitors such as PD-1/PD-L1, the induction of ADCC, ADCP and/or CDC would potentially lead to the destruction of normal immune cells. For this specific application, the therapeutic antibody functions to block the inhibitory signal leading to the induction of an immune response. For instance, nivolumab is a human IgG4 isotype with an S228P mutation, which replaces a serine (S) residue in the hinge region with a proline $(\mathrm{P})$ that prevents Fab arm exchange with endogenous IgG4 antibodies, while retaining the low affinity for activating Fc receptors associated with wild-type IgG4 antibodies. In fact, no in vitro ADCC or CDC activity was observed with nivolumab in assays using PD-1-expressing activated T cells as target cells (146).

Human IgG1 has also been modified to attenuate the effector functions. For instance, abatacept $\left(\right.$ Orencia $\left.{ }^{\circledR}\right)$ is an FDAapproved fusion protein consisting of the external domain of human CTLA- 4 and the Fc region of human IgG1 that contains four mutations: C130S/C136S/C139S/P148S. Abatacept does not induce ADCC against the human B cell line PM-LCL that expresses CD80 and CD86, which interact with CTLA-4 (122). Note that in case of abatacept binding to the targeted cells occurs via CTLA-4 and not via a variable region of an antibody. These constructs are known as immunoadhesins because they have an adhesive molecule linked to an antibody Fc fragment. Another example is an Fc-engineered anti-CD70 IgG1 that contains five mutations (C226S/C229S/E233P/L234V/L235A) and shows decreased ADCP activity (123). Furthermore, a human IgG3 targeting the transferrin receptor 1 (TfR1) containing only two mutations (L234A/L235A) showed decreased ADCC activity against TfR1 expressing target cells, an effect that was increased by the addition of a third mutation P329S (125). However, the P329S single mutant showed no effect on ADCC (125).

Similar to ADCC and ADCP, there are instances where the induction of CDC may be harmful. For example, $\mathrm{CDC}$ has been associated with injection site reactions (147). Additionally, it has been reported that complement activation may interfere with the induction of ADCC (148). Therefore, for antibodies that have CDC-related toxicities, eliminating the ability of the antibody to elicit CDC would be advantageous. For example, the abatacept fusion protein containing the four mutations C130S/C136S/ C139S/P148S that lacks ADCC activity as discussed above, also does not induce CDC against a human B cell line, PM-LCL (122). However, for antibodies in which ADCC is a major antitumor mechanism, a mutant that elicits ADCC but not CDC may be the most efficacious. The C1q binding "epicenter" of human IgG1 has been localized to D270, K322, P329, and P331 (129). Point mutations at any one of these sites in rituximab decreased CDC activity, but not ADCC or binding to FcRn (129). In a human IgG3 targeting TfR1, the P329S mutation abolished CDC activity against TfR1 expressing target cells, but no impaired ADCC was detected with this single mutation (125).

\section{Glycoengineering}

Glycosylation of an antibody can also alter its function. Asparagine-297 (N297) in the $\mathrm{C}_{\mathrm{H}} 2$ domain is conserved among the IgG subclasses (149). Glycosylation at this residue stabilizes the Fc region and keeps it in an open conformation (150). This glycosylation is critical for binding to the activating FcyRs and 
the induction of ADCC. However, if glycosylation is completely eliminated at this site, the $\mathrm{C}_{\mathrm{H}} 2$ domains collapse inward and binding to FcyRs is lost (149). For example, mutation of this residue to alanine (N297A) eliminates glycosylation and results in an antibody that is unable to bind activating Fc $\gamma$ Rs (151). Mutation of the nearby residue threonine 299 to leucine (T299L) leads to a similar effect since T299 is considered to be part of the "glycosylation motif" that is important for glycosylation of this residue (N297) (128). Antibodies containing the T299L mutation are unable to elicit ADCC against cancer cells (128).

Modulation of the specific carbohydrate composition at N297 can have the opposite effect and enhance the ADCC activity of the antibody. The affinity of an antibody for the activating FcyRs depends on the composition of the N297 N-linked oligosaccharide (152). There are 32 different possible combinations of oligosaccharides that can occur at this site (150). Naturally occurring human IgG and those produced by hybridomas or other common expression systems (including murine myeloma cells such as SP2/0-Ag14, P3X63Ag8.653, and NS0/1; CHO cells; and HEK cells) are usually composed of $\mathrm{N}$-acetylglucosamine (GlcNAc) and three mannose residues that form a core carbohydrate. This core is attached to two additional GlcNAc groups to form biantennary branches (150). The addition of galactose at each branch can occur as well as the terminal addition of sialic acid to these galactose molecules. Fucose is often part of the core GlcNAc. This fucose, through steric hindrance, obstructs the interaction of the antibody with the Fc $\gamma$ RIIIA $(149,150)$. Thus, elimination of this fucose molecule while maintaining other forms of glycosylation at this site increases the binding of the antibody to the activating Fc $\gamma$ Rs, enhancing its ability to elicit ADCC and $\operatorname{ADCP}(152,153)$.
Elimination of the fucose at N297 can be achieved by glycoengineering through various methods to produce afucosylated antibodies that have enhanced ADCC capabilities. Examples are shown in Table 4. The use of an expression system that is unable to attach fucose molecules to the antibody is a common way to produce afucosylated antibodies. FUT8 encodes the fucosyltransferase enzyme that is responsible for the addition of fucose during protein synthesis. Thus, cells that lack or express low levels of this enzyme produce proteins that lack fucosylation. Rat YB2/0 cells are commonly used for this purpose and many different wild-type and Fc-mutated antibodies that show increased ADCC activity have been produced in these cells $(127,134,154,155)$.

Alternatively, siRNA can be used to knock down the expression of this enzyme in commonly used expression systems or exogenous expression of various other glycotransferases can force a specific type of glycosylation at N297, both leading to afucosylation at this residue. For example, overexpression of the glycotransferase $\beta(1,4)-N$-acetylglucosaminyltransferase III (GnTIII), which catalyzes the addition of bisecting GlcNAc, in $\mathrm{CHO}$ cells yielded an IgG with reduced core fucosylation and enhanced ADCC (161). This technology is now known as GlycoMab (162). Obinutuzumab, produced using the GlycoMab Technology, was approved by the FDA in 2013 as part of a combination therapy for previously untreated patients with chronic lymphocytic leukemia and later in 2016 as part of a combination therapy for patients with follicular lymphoma that are refractory to or have relapsed after treatment with rituximab $(168,169)$. Metabolic interference with host biosynthesis pathways through the addition of kifunensine, an inhibitor of the $\mathrm{N}$-linked glycosylation pathway, to the growth medium during production can

TABLE 4 | Glycoengineering examples to enhance ADCC.

\begin{tabular}{|c|c|c|c|}
\hline Cell line & Species and cell type & Description & Reference \\
\hline Ms704 & $\begin{array}{l}\text { Hamster ovary (CHO/DG44 } \\
\text { variant) }\end{array}$ & FUT8 knock out & $(156)$ \\
\hline LEC13 & Hamster ovary (CHO variant) & Deficient in GDP-mannose 4,6 dehydratase (GMD) & (157) \\
\hline $\mathrm{CHO}$ & Hamster ovary & Fucosyltransferase-deficient (Biowa Potelligent Technology) & (158) \\
\hline $\mathrm{CHO}$ & Hamster ovary & siRNA knockdown of $\alpha 1,6$ fucosylatransferase & (159) \\
\hline $\mathrm{CHO}$ & Hamster ovary & Overexpression of GnTIII (GlycoMab Technology) & $(161,162)$ \\
\hline HEK293F & Human embryonic kidney & $\begin{array}{l}\text { Addition of kifunensine to growth medium to inhibit the } N \text {-linked } \\
\text { glycosylation pathway }\end{array}$ & (163) \\
\hline HEK293-EBNA & Human embryonic kidney & $\begin{array}{l}\text { Exogenous transient expression of chimeric protein, a fusion } \\
\text { between the catalytic domain } \beta 1,4-N \text {-acetylglucosaminyltransferase } \\
\text { III and the localization domains of Golgi-resident enzymes }\end{array}$ & (164) \\
\hline Strains YAS309 & Pichia pastoris (yeast) & $\begin{array}{l}\text { Expression of Kluyveromyces lactis UDP-GlcNAc transporter, } \\
\alpha 1,2 \text { Mus musculus Mnsl, } \beta 1,2 \text { GlcNAc transferase I, } \beta 1,2 \text { Rattus } \\
\text { norvegicus GlcNAc transferase II, Drosophila melanogaster Mnsll, } \\
\text { Schizosaccharomyces pombe Gal epimerase, Drosophilia melanogaster } \\
\text { UDP-Gal transporter, Homo sapiens } \beta 1,4 \text { galactosyl transferase }\end{array}$ & (167) \\
\hline
\end{tabular}

$\mathrm{CHO}$, Chinese hamster ovary; HEK, human embryonic kidney. 
also result in antibodies with low fucose levels and enhanced ADCC activity. Other eukaryotic expression systems can also be glycoengineered to produce antibodies with low fucose levels (165-167).

\section{Mutations to Alter Half-Life}

Altering the interaction between FcRn and antibodies may lead to the development of antibodies with higher efficacy due to altered pharmacokinetic and pharmacodynamic properties. Binding of human IgG to FcRn is $\mathrm{pH}$ dependent where binding occurs within a pH range of 6-6.5 and release occurs at pH 7.0-7.5 (170-172). IgG is taken up by endothelial cells through pinocytosis, binds the FcRn in endosomes where the $\mathrm{pH}$ is 6.0-6.5, and is recycled back to the cell surface where the IgG is released due to the neutral $\mathrm{pH}$ of blood. If an antibody does not bind the $\mathrm{FcRn}$, it is routed to the lysosomal pathway where degradation occurs. Thus, binding of IgG to the FcRn is important to prolong the half-life since this interaction rescues the antibody from degradation. For this reason, the FcRn is known as the "salvage receptor."

The serum half-life of human IgG1, IgG2, and IgG4 is 21 days, while that of IgG3 is 5-7.5 days (Table 2). Human IgG3 differs from human IgG1 at residue 435. IgG3 contains arginine (R), while IgG1 contains histidine $(\mathrm{H})$ at this position. Both isotypes show pH-dependent binding to A375 human melanoma cells expressing the human FcRn $\alpha$ chain and that transport of both classes is equally efficient in an in vitro transport model using these cells (135). However, when both subclasses are present, IgG1 inhibits IgG3 transport leading to its degradation, which can help to explain its shorter half-life. An R435H variant of IgG3 shows similar half-life to human IgG1 (135).

Increasing the serum half-life of IgG1 can also be advantageous to reduce the frequency of administration of the treatment and enhance efficacy. Residues I253, S254, H435, and Y436 play a relevant role in binding of IgG to FcRn since single alanine (A) substitutions at any of these residues substantially decreases binding to the FcRn $(113,173)$. Using random mutagenesis and a pHdependent phage display for selection, numerous mutations have been identified that showed increased binding to human FcRn and increased persistence in human FcRn transgenic mice (127). An N434A mutant of a humanized IgG1 antibody showed increased half-life in cynomolgus monkeys (Macaca fasicularis) compared to the wild-type IgG1 antibody targeting the B-cell surface receptor (132). This mutant had increased binding affinity to human and monkey FcRn at $\mathrm{pH}$ 6, but negligible binding to $\mathrm{FcRn}$ at $\mathrm{pH}$ 7.4. Mutant N434W had increased binding at both $\mathrm{pH}$ and did not show this increase in half-life, demonstrating the $\mathrm{pH}$-dependent binding of IgG to FcRn (132). The triple mutant M252Y/S254T/ T256E (YTE) of an anti-respiratory syncytial virus IgG1 also shows $\mathrm{pH}$-dependent binding including increased binding to human and cynomolgus monkey $\mathrm{FcRn}$ at $\mathrm{pH} 6.0$ and efficient release at $\mathrm{pH} 7.4$, which results in a four-fold increase in serum half-life in cynomolgus monkeys (124). Furthermore, this YTE mutant showed increased serum half-life in healthy humans (174).

There may be cases in which a reduction in serum half-life may be advantageous. For example, if the antibody is conjugated to a toxic compound, a longer half-life may lead to more unwanted side effects. For example, the I253A mutant of trastuzumab did not bind FcRn in vitro and showed enhanced clearance in human FcRn transgenic mice (131). However, it should be noted that other human IgG1 mutants P257I/Q311I, P257I/N434H, and D376V/N434H specific for tumor necrosis factor-alpha (TNF- $\alpha$ ) that showed increased in vitro binding to human, cynomolgus, and mouse $\mathrm{FcRn}$ at $\mathrm{pH} 6$ and no binding at $\mathrm{pH}$ 7.4, paradoxically had increased clearance in CD-1 and C57BL/6 mice (136). The serum half-life of these mutants (P257I/N434H and D376V/ $\mathrm{N} 434 \mathrm{H}$ ) was similar to that of the wild-type IgG1 in cynomolgus monkeys (136).

\section{CONCLUDING REMARKS AND FUTURE DEVELOPMENTS}

In the last 40 years, after the seminal work by Köhler and Milstein, academic laboratories and the biopharmaceutical industry have achieved remarkable progress in the engineering and clinical development of therapeutic antibodies, leading to the approval of 21 antibodies for diverse indications in oncology. $\mathrm{V}$ region discovery and engineering platforms have evolved from selecting and developing mouse and rat monoclonal antibodies to engineering chimeric antibodies by joining rodent $\mathrm{V}$ regions with human $\mathrm{C}$ regions, to humanized antibodies by rodent $\mathrm{CDR}$ grafting into human FRs, to fully human antibodies developed via phage display or transgenic animals. Fully human antibodies have a higher human content, with some antibodies being in the germline gene configuration and, thus, in principle having minimal immunogenicity.

Although these technology platforms have matured, additional incremental but important improvements are still in progress. For instance, humanization of the CDRs is leading to humanized antibodies indistinguishable from fully human antibodies. Better and more diverse phage display antibody libraries are now available. These libraries are built with variable regions with high expression levels in production cells, highly soluble and more stable than the initial naive libraries composed of the entire repertoire of human antibodies, some of which may not be developable. Importantly, humanization platforms and phage display methodology are now off patent thus, becoming commodities, which make them accessible to academic laboratories and small biotech companies at a lower cost, fostering more innovation and further exploration of diverse and novel targets. In addition, other platforms such as yeast display have been developed, which allows for efficient selection of high affinity antibodies and full IgG with diverse $\mathrm{Fc}$ isotypes and glycosylation. More efficient transgenic mice and transgenic species other than the mouse, such as the chicken, have been generated, which can tackle some of the limitations of the early transgenic mice and expand the possibilities of obtaining antibodies targeting conversed epitopes in human and murine orthologs.

On other hand, in the last 15 years, as more antibodies have been approved for therapeutic settings and many failed to perform in preclinical development and clinical trials, a set of design principles and experimental methods have been implemented to ensure further development or manufacturing of antibodies with therapeutic potential. This has been particularly important for therapeutic antibodies generated via phage display and related 
enriching technologies. Perfecting predictive algorithms to spot in the design phase potential developability issues and applying robust developability experimental methods as early as possible in the antibody discovery phase to select the molecules to further develop should reduce costs and enable more companies to advance fully human antibodies faster and with a higher probability of success in clinical development.

In parallel with the advances in the $\mathrm{V}$ region engineering, the $\mathrm{Fc}$ has been extensively modified to enhance or attenuate ADCC, ADCP, and/or CDC and thus, tailor the effector functions of therapeutic antibodies to diverse MOAs. Modifications in the residues interacting with the FcRn to extend the half-life of antibodies have been also reported. These modifications are having an impact on dosage and cost of goods, with the ultimate benefit for the treatment of patients. Several of the Fc modifications are being validated in preclinical development and clinical trials and hence it is expected that more therapeutic antibodies with engineered $\mathrm{Fc}$ mutations will be approved soon. Beyond IgG, the class of choice for all the approved therapeutic antibodies used for oncologic applications, other classes of antibodies such as IgA (175) and IgE (176) are emerging as new options for cancer therapy. These new options, together with the outstanding

\section{REFERENCES}

1. Köhler G, Milstein C. Continuous cultures of fused cells secreting antibody of predefined specificity. Nature (1975) 256:495-7. doi:10.1038/256495a0

2. Reichert JM. Antibodies to watch in 2017. MAbs (2017) 9(2):167-81. doi:10. 1080/19420862.2016.1269580

3. Strohl WR. Current progress in innovative engineered antibodies. Protein Cell (2017). doi:10.1007/s13238-017-0457-8

4. Smith SL. Ten years of orthoclone OKT3 (muromonab-CD3): a review. J Transpl Coord (1996) 6(3):109-19; quiz 120-1. doi:10.1177/090591999 600600304

5. Emmons C, Hunsicker LG. Muromonab-CD3 (Orthoclone OKT3): the first monoclonal antibody approved for therapeutic use. Iowa Med (1987) $77(2): 78-82$.

6. Kimball JA, Norman DJ, Shield CF, Schroeder TJ, Lisi P, Garovoy M, et al. OKT3 antibody response study (OARS): a multicenter comparative study. Transplant Proc (1993) 25(1 Pt 1):558-60.

7. Shawler DL, Bartholomew RM, Smith LM, Dillman RO. Human immune response to multiple injections of murine monoclonal IgG. J Immunol (1985) 135(2):1530-5.

8. Bruhns P, Jonsson F. Mouse and human FcR effector functions. Immunol Rev (2015) 268(1):25-51. doi:10.1111/imr.12350

9. Ober RJ, Radu CG, Ghetie V, Ward ES. Differences in promiscuity for antibody-FcRn interactions across species: implications for therapeutic antibodies. Int Immunol (2001) 13(12):1551-9. doi:10.1093/intimm/13.12.1551

10. Morrison SL, Johnson MJ, Herzenberg LA, Oi VT. Chimeric human antibody molecules: mouse antigen-binding domains with human constant region domains. Proc Natl Acad Sci US A (1984) 81(21):6851-5. doi:10.1073/pnas.81. 21.6851

11. Jones PT, Dear PH, Foote J, Neuberger MS, Winter G. Replacing the complementarity-determining regions in a human antibody with those from a mouse. Nature (1986) 321(6069):522-5. doi:10.1038/321522a0

12. McCafferty J, Griffiths AD, Winter G, Chiswell DJ. Phage antibodies: filamentous phage displaying antibody variable domains. Nature (1990) 348(6301):552-4. doi:10.1038/348552a0

13. Green LL, Hardy MC, Maynard-Currie CE, Tsuda H, Louie DM, Mendez MJ, et al. Antigen-specific human monoclonal antibodies from mice engineered with human Ig heavy and light chain YACs. Nat Genet (1994) 7(1):13-21. doi:10.1038/ng0594-13 progress in the development of antibody engineering methods to modify the $\mathrm{V}$ regions should lead to a profound impact in the therapy of cancer in the near future.

\section{AUTHOR CONTRIBUTIONS}

JA and MP devised the concept of the review and contributed to the overall direction of the manuscript including the general writing, preparation of the figures, and editing processes. JA contributed the sections on antibody engineering. TD-W contributed to the writing and editing of the manuscript with an emphasis on the Fc-engineering section. SP-T and JA contributed the section on the targeted molecules.

\section{ACKNOWLEDGMENTS}

The authors would like to thank Dr. Gabriela Canziani for her help to define the scope of the review and fruitful discussions during the preparation of the manuscript. Our studies on antibodies have been supported in part by NIH grants R01CA168482, R01CA196266, R01CA196266-01A1:S1, P30AI028697, and P30CA016042.
14. Lonberg N, Taylor LD, Harding FA, Trounstine M, Higgins KM, Schramm SR et al. Antigen-specific human antibodies from mice comprising four distinct genetic modifications. Nature (1994) 368(6474):856-9. doi:10.1038/368856a0

15. Clynes RA, Towers TL, Presta LG, Ravetch JV. Inhibitory Fc receptors modulate in vivo cytotoxicity against tumor targets. Nat Med (2000) 6(4):443-6. doi: $10.1038 / 74704$

16. Jakobovits A, Amado RG, Yang X, Roskos L, Schwab G. From XenoMouse technology to panitumumab, the first fully human antibody product from transgenic mice. Nat Biotechnol (2007) 25(10):1134-43. doi:10.1038/ nbt1337

17. Beck A, Goetsch L, Dumontet C, Corvaia N. Strategies and challenges for the next generation of antibody-drug conjugates. Nat Rev Drug Discov (2017) 16(5):315-37. doi:10.1038/nrd.2016.268

18. Mattes MJ. Radionuclide-antibody conjugates for single-cell cytotoxicity. Cancer (2002) 94(4 Suppl):1215-23. doi:10.1002/cncr.10288

19. Alewine C, Hassan R, Pastan I. Advances in anticancer immunotoxin therapy. Oncologist (2015) 20(2):176-85. doi:10.1634/theoncologist.2014-0358

20. Ortiz-Sanchez E, Helguera G, Daniels TR, Penichet ML. Antibody-cytokine fusion proteins: applications in cancer therapy. Expert Opin Biol Ther (2008) 8(5):609-32. doi:10.1517/14712598.8.5.609

21. Brinkmann U, Kontermann RE. The making of bispecific antibodies. MAbs (2017) 9(2):182-212. doi:10.1080/19420862.2016.1268307

22. Payes CJ, Daniels-Wells TR, Maffia PC, Penichet ML, Morrison SL, Helguera G. Genetic engineering of antibody molecules. In: Meyers RA, editor. Reviews in Cell Biology and Molecular Medicine. Weinheim: Wiley-VCH Verlag GmbH \& Co. (2015). p. 1-52.

23. Saphire EO, Parren PW, Pantophlet R, Zwick MB, Morris GM, Rudd PM, et al. Crystal structure of a neutralizing human IGG against HIV-1: a template for vaccine design. Science (2001) 293(5532):1155-9. doi:10.1126/ science. 1061692

24. Finlay WJ, Almagro JC. Natural and man-made V-gene repertoires for antibody discovery. Front Immunol (2012) 3:342. doi:10.3389/fimmu.2012.00342

25. Tonegawa S. Somatic generation of antibody diversity. Nature (1983) 302(5909):575-81. doi:10.1038/302575a0

26. Neuberger MS. Antibody diversification by somatic mutation: from Burnet onwards. Immunol Cell Biol (2008) 86(2):124-32. doi:10.1038/sj.icb.7100160

27. Mage RG, Lanning D, Knight KL. B cell and antibody repertoire development in rabbits: the requirement of gut-associated lymphoid tissues. Dev Comp Immunol (2006) 30(1-2):137-53. doi:10.1016/j.dci.2005.06.017 
28. Sondermann P, Szymkowski DE. Harnessing Fc receptor biology in the design of therapeutic antibodies. Curr Opin Immunol (2016) 40:78-87. doi:10.1016/j.coi.2016.03.005

29. Strohl WR, Strohl LM. Therapeutic antibody classes. In: Strohl LM, editor. Therapeutic Antibody Engineering: Current and Future Advances Driving the Strongest Growth Area in the Pharmaceutical Industry. 1st ed. Sawston: Woodhead Publishing (2012). p. 197-223.

30. Bruggemann M, Williams GT, Bindon CI, Clark MR, Walker MR, Jefferis R, et al. Comparison of the effector functions of human immunoglobulins using a matched set of chimeric antibodies. J Exp Med (1987) 166(5):1351-61. doi:10.1084/jem.166.5.1351

31. Chiavenna SM, Jaworski JP, Vendrell A. State of the art in anti-cancer mAbs. J Biomed Sci (2017) 24(1):15. doi:10.1186/s12929-016-0311-y

32. Klein C, Lammens A, Schafer W, Georges G, Schwaiger M, Mossner E, et al. Epitope interactions of monoclonal antibodies targeting CD20 and their relationship to functional properties. MAbs (2013) 5(1):22-33. doi:10.4161/ mabs.22771

33. Klein C, Lammens A, Schafer W, Georges G, Schwaiger M, Mossner E, et al. Response to: monoclonal antibodies targeting CD20. MAbs (2013) 5(3):337-8. doi:10.4161/mabs.24108

34. Niederfellner G, Lammens A, Mundigl O, Georges GJ, Schaefer W, Schwaiger M, et al. Epitope characterization and crystal structure of GA101 provide insights into the molecular basis for type I/II distinction of CD20 antibodies. Blood (2011) 118(2):358-67. doi:10.1182/blood-2010-09-305847

35. Du J, Wang H, Zhong C, Peng B, Zhang M, Li B, et al. Structural basis for recognition of CD20 by therapeutic antibody Rituximab. J Biol Chem (2007) 282(20):15073-80. doi:10.1074/jbc.M701654200

36. Taylor JM, Mitchell WM, Cohen S. Characterization of the binding protein for epidermal growth factor. J Biol Chem (1974) 249(7):2188-94.

37. Downward J, Yarden Y, Mayes E, Scrace G, Totty N, Stockwell P, et al. Close similarity of epidermal growth factor receptor and v-erb-B oncogene protein sequences. Nature (1984) 307(5951):521-7. doi:10.1038/307521a0

38. Kovacs E, Zorn JA, Huang Y, Barros T, Kuriyan J. A structural perspective on the regulation of the epidermal growth factor receptor. Annu Rev Biochem (2015) 84:739-64. doi:10.1146/annurev-biochem-060614-034402

39. Li S, Kussie P, Ferguson KM. Structural basis for EGF receptor inhibition by the therapeutic antibody IMC-11F8. Structure (2008) 16(2):216-27. doi:10.1016/j.str.2007.11.009

40. Voigt M, Braig F, Gothel M, Schulte A, Lamszus K, Bokemeyer C, et al. Functional dissection of the epidermal growth factor receptor epitopes targeted by panitumumab and cetuximab. Neoplasia (2012) 14(11):1023-31. doi:10.1593/neo.121242

41. Montagut C, Dalmases A, Bellosillo B, Crespo M, Pairet S, Iglesias M, et al. Identification of a mutation in the extracellular domain of the epidermal growth factor receptor conferring cetuximab resistance in colorectal cancer. Nat Med (2012) 18(2):221-3. doi:10.1038/nm.2609

42. Cho HS, Mason K, Ramyar KX, Stanley AM, Gabelli SB, Denney DW Jr, et al. Structure of the extracellular region of HER2 alone and in complex with the Herceptin Fab. Nature (2003) 421(6924):756-60. doi:10.1038/nature01392

43. Nami B, Wang Z. HER2 in breast cancer stemness: a negative feedback loop towards trastuzumab resistance. Cancers (Basel) (2017) 9(5):1-33. doi: $10.3390 /$ cancers 9050040

44. Harbeck N, Beckmann MW, Rody A, Schneeweiss A, Muller V, Fehm T, et al. HER2 dimerization inhibitor pertuzumab - mode of action and clinical data in breast cancer. Breast Care (Basel) (2013) 8(1):49-55. doi:10.1159/000346837

45. Fabi A, Malaguti P, Vari S, Cognetti F. First-line therapy in HER2 positive metastatic breast cancer: is the mosaic fully completed or are we missing additional pieces? JExp Clin Cancer Res (2016) 35:104. doi:10.1186/ s13046-016-0380-5

46. Mullard A. New checkpoint inhibitors ride the immunotherapy tsunami. Nat Rev Drug Discov (2013) 12(7):489-92. doi:10.1038/nrd4066

47. Cogdill AP, Andrews MC, Wargo JA. Hallmarks of response to immune checkpoint blockade. Br J Cancer (2017) 117(1):1-7. doi:10.1038/bjc.2017.136

48. SharmaP, Callahan MK, BonoP, Kim J,Spiliopoulou P, CalvoE, etal.Nivolumab monotherapy in recurrent metastatic urothelial carcinoma (CheckMate 032): a multicentre, open-label, two-stage, multi-arm, phase 1/2 trial. Lancet Oncol (2016) 17(11):1590-8. doi:10.1016/S1470-2045(16)30496-X
49. Zak KM, Grudnik P, Magiera K, Domling A, Dubin G, Holak TA. Structural biology of the immune checkpoint receptor PD-1 and its ligands PD-L1/ PD-L2. Structure (2017) 25(8):1163-74. doi:10.1016/j.str.2017.06.011

50. Na Z, Yeo SP, Bharath SR, Bowler MW, Balikci E, Wang CI, et al. Structural basis for blocking PD-1-mediated immune suppression by therapeutic antibody pembrolizumab. Cell Res (2017) 27(1):147-50. doi:10.1038/cr.2016.77

51. Ghiotto M, Gauthier L, Serriari N, Pastor S, Truneh A, Nunes JA, et al. PD-L1 and PD-L2 differ in their molecular mechanisms of interaction with PD-1. Int Immunol (2010) 22(8):651-60. doi:10.1093/intimm/dxq049

52. Tan S, Liu K, Chai Y, Zhang CW, Gao S, Gao GF, et al. Distinct PD-L1 binding characteristics of therapeutic monoclonal antibody durvalumab. Protein Cell (2017). doi:10.1007/s13238-017-0412-8

53. Jahn EM, Schneider CK. How to systematically evaluate immunogenicity of therapeutic proteins - regulatory considerations. N Biotechnol (2009) 25(5):280-6. doi:10.1016/j.nbt.2009.03.012

54. Gunn GR III, Sealey DC, Jamali F, Meibohm B, Ghosh S, Shankar G. From the bench to clinical practice: understanding the challenges and uncertainties in immunogenicity testing for biopharmaceuticals. Clin Exp Immunol (2016) 184(2):137-46. doi:10.1111/cei.12742

55. Landsteiner K, van der Scheer J. On the serological specificity of peptides. J Exp Med (1932) 55(5):781-96. doi:10.1084/jem.55.5.781

56. Eck RV, Dayhoff MO. Evolution of the structure of ferredoxin based on living relics of primitive amino acid sequences. Science (1966) 152(3720):363-6. doi:10.1126/science.152.3720.363

57. Jawa V, Cousens LP, Awwad M, Wakshull E, Kropshofer H, De Groot AS. T-cell dependent immunogenicity of protein therapeutics: preclinical assessment and mitigation. Clin Immunol (2013) 149(3):534-55. doi:10.1016/j. clim.2013.09.006

58. Tomlinson IM, Walter G, Marks JD, Llewelyn MB, Winter G. The repertoire of human germline $\mathrm{VH}$ sequences reveals about fifty groups of $\mathrm{VH}$ segments with different hypervariable loops. J Mol Biol (1992) 227(3):776-98. doi:10.1016/0022-2836(92)90223-7

59. Schable K, Thiebe R, Flugel A, Meindl A, Zachau HG. The human immunoglobulin kappa locus: pseudogenes, unique and repetitive sequences. Biol Chem HoppeSeyler (1994) 375(3):189-99. doi:10.1515/bchm3.1994.375.3.189

60. Matsuda F, Ishii K, Bourvagnet $\mathrm{P}$, Kuma K, Hayashida H, Miyata T, et al. The complete nucleotide sequence of the human immunoglobulin heavy chain variable region locus. J Exp Med (1998) 188(11):2151-62. doi:10.1084/ jem.188.11.2151

61. Watson CT, Steinberg KM, Huddleston J, Warren RL, Malig M, Schein J, et al. Complete haplotype sequence of the human immunoglobulin heavy-chain variable, diversity, and joining genes and characterization of allelic and copy-number variation. Am J Hum Genet (2013) 92(4):530-46. doi:10.1016/j. ajhg.2013.03.004

62. Gadala-Maria D, Yaari G, Uduman M, Kleinstein SH. Automated analysis of high-throughput B-cell sequencing data reveals a high frequency of novel immunoglobulin V gene segment alleles. Proc Natl Acad Sci U S A (2015) 112(8):E862-70. doi:10.1073/pnas.1417683112

63. Tomlinson IM, Walter G, Jones PT, Dear PH, Sonnhammer EL, Winter G. The imprint of somatic hypermutation on the repertoire of human germline V genes. J Mol Biol (1996) 256(5):813-7. doi:10.1006/jmbi.1996.0127

64. Ramirez-Benitez MC, Almagro JC. Analysis of antibodies of known structure suggests a lack of correspondence between the residues in contact with the antigen and those modified by somatic hypermutation. Proteins (2001) 45(3):199-206. doi:10.1002/prot.1140

65. Clark LA, Ganesan S, Papp S, van Vlijmen HW. Trends in antibody sequence changes during the somatic hypermutation process. JImmunol (2006) 177(1):333-40. doi:10.4049/jimmunol.177.1.333

66. Knox C, Law V, Jewison T, Liu P, Ly S, Frolkis A, et al. DrugBank 3.0: a comprehensive resource for 'omics' research on drugs. Nucleic Acids Res (2011) 39(Database issue):D1035-41. doi:10.1093/nar/gkq1126

67. Jain T, Sun T, Durand S, Hall A, Houston NR, Nett JH, et al. Biophysical properties of the clinical-stage antibody landscape. Proc Natl Acad Sci U S A (2017) 114(5):944-9. doi:10.1073/pnas.1616408114

68. Chothia C, Lesk AM. Canonical structures for the hypervariable regions of immunoglobulins. J Mol Biol (1987) 196(4):901-17. doi:10.1016/00222836(87)90412-8 
69. Kabat EA, Wu TT, Perry H, Gottesman K, Foeller C. Sequences of Proteins of Immunological Interest. 5th ed. Bethesda, MD: US Department of Health and Human Services, Public Health Service, NIH (1991). NIH Publication No. 91-3242.

70. Goldstein NI, Prewett M, Zuklys K, Rockwell P, Mendelsohn J. Biological efficacy of a chimeric antibody to the epidermal growth factor receptor in a human tumor xenograft model. Clin Cancer Res (1995) 1(11):1311-8.

71. Gillies SD, Lo KM, Wesolowski J. High-level expression of chimeric antibodies using adapted cDNA variable region cassettes. J Immunol Methods (1989) 125(1-2):191-202. doi:10.1016/0022-1759(89)90093-8

72. Mueller BM, Romerdahl CA, Gillies SD, Reisfeld RA. Enhancement of antibody-dependent cytotoxicity with a chimeric anti-GD2 antibody. J Immunol (1990) 144(4):1382-6.

73. Hwang WY, Foote J. Immunogenicity of engineered antibodies. Methods (2005) 36(1):3-10. doi:10.1016/j.ymeth.2005.01.001

74. Riechmann L, Clark M, Waldmann H, Winter G. Reshaping human antibodies for therapy. Nature (1988) 332(6162):323-7. doi:10.1038/332323a0

75. Saul FA, Amzel LM, Poljak RJ. Preliminary refinement and structural analysis of the Fab fragment from human immunoglobulin new at 2.0 A resolution. J Biol Chem (1978) 253(2):585-97.

76. Epp O, Lattman EE, Schiffer M, Huber R, Palm W. The molecular structure of a dimer composed of the variable portions of the Bence-Jones protein REI refined at 2.0-A resolution. Biochemistry (1975) 14(22):4943-52. doi:10.1021/ bi00693a025

77. Queen C, Schneider WP, Selick HE, Payne PW, Landolfi NF, Duncan JF, et al. A humanized antibody that binds to the interleukin 2 receptor. Proc Natl Acad Sci U S A (1989) 86(24):10029-33. doi:10.1073/pnas.86.24. 10029

78. Carter P, Presta L, Gorman CM, Ridgway JB, Henner D, Wong WL, et al. Humanization of an anti-p185HER2 antibody for human cancer therapy. Proc Natl Acad Sci U S A (1992) 89(10):4285-9. doi:10.1073/pnas. 89.10.4285

79. Presta LG, Chen H, O’Connor SJ, Chisholm V, Meng YG, Krummen L, et al. Humanization of an anti-vascular endothelial growth factor monoclonal antibody for the therapy of solid tumors and other disorders. Cancer Res (1997) 57(20):4593-9.

80. Adams CW, Allison DE, Flagella K, Presta L, Clarke J, Dybdal N, et al. Humanization of a recombinant monoclonal antibody to produce a therapeutic HER dimerization inhibitor, pertuzumab. Cancer Immunol Immunother (2006) 55(6):717-27. doi:10.1007/s00262-005-0058-x

81. Hwang WY, Almagro JC, Buss TN, Tan P, Foote J. Use of human germline genes in a CDR homology-based approach to antibody humanization. Methods (2005) 36(1):35-42. doi:10.1016/j.ymeth.2005.01.004

82. Fransson J, Teplyakov A, Raghunathan G, Chi E, Cordier W, Dinh T, et al. Human framework adaptation of a mouse anti-human IL-13 antibody. J Mol Biol (2010) 398(2):214-31. doi:10.1016/j.jmb.2010.03.004

83. Almagro JC, Fransson J. Humanization of antibodies. Front Biosci (2008) 13:1619-33.

84. Nechansky A. HAHA - nothing to laugh about. Measuring the immunogenicity (human anti-human antibody response) induced by humanized monoclonal antibodies applying ELISA and SPR technology. J Pharm Biomed Anal (2010) 51(1):252-4. doi:10.1016/j.jpba.2009.07.013

85. Winter GP. Altered Antibodies. (1986). US 6,548,640.

86. Queen CL, Selick HE. Humanized Immunoglobulins. (1988). US 5,585,089.

87. Bernett MJ, Karki S, Moore GL, Leung IW, Chen H, Pong E, et al. Engineering fully human monoclonal antibodies from murine variable regions. J Mol Biol (2010) 396(5):1474-90. doi:10.1016/j.jmb.2009.12.046

88. Harding FA, Stickler MM, Razo J, DuBridge RB. The immunogenicity of humanized and fully human antibodies: residual immunogenicity resides in the CDR regions. MAbs (2010) 2(3):256-65. doi:10.4161/mabs.2.3.11641

89. Townsend S, Fennell BJ, Apgar JR, Lambert M, McDonnell B, Grant J, et al. Augmented binary substitution: single-pass CDR germ-lining and stabilization of therapeutic antibodies. Proc Natl Acad Sci U S A (2015) 112(50):15354-9. doi:10.1073/pnas.1510944112

90. Apgar JR, Mader M, Agostinelli R, Benard S, Bialek P, Johnson M, et al. Beyond CDR-grafting: structure-guided humanization of framework and CDR regions of an anti-myostatin antibody. MAbs (2016) 8(7):1302-18. doi: $10.1080 / 19420862.2016 .1215786$
91. Lonberg N. Fully human antibodies from transgenic mouse and phage display platforms. Curr Opin Immunol (2008) 20(4):450-9. doi:10.1016/j. coi.2008.06.004

92. Yang XD, Jia XC, Corvalan JR, Wang P, Davis CG, Jakobovits A. Eradication of established tumors by a fully human monoclonal antibody to the epidermal growth factor receptor without concomitant chemotherapy. Cancer Res (1999) 59(6):1236-43.

93. Kellermann SA, Green LL. Antibody discovery: the use of transgenic mice to generate human monoclonal antibodies for therapeutics. Curr Opin Biotechnol (2002) 13(6):593-7. doi:10.1016/S0958-1669(02)00354-3

94. Lee EC, Liang Q, Ali H, Bayliss L, Beasley A, Bloomfield-Gerdes T, et al. Complete humanization of the mouse immunoglobulin loci enables efficient therapeutic antibody discovery. Nat Biotechnol (2014) 32(4):356-63. doi:10.1038/nbt. 2825

95. Murphy AJ, Macdonald LE, Stevens S, Karow M, Dore AT, Pobursky K, et al. Mice with megabase humanization of their immunoglobulin genes generate antibodies as efficiently as normal mice. Proc Natl Acad Sci U S A (2014) 111(14):5153-8. doi:10.1073/pnas.1324022111

96. Green LL, Jakobovits A. Regulation of B cell development by variable gene complexity in mice reconstituted with human immunoglobulin yeast artificial chromosomes. J Exp Med (1998) 188(3):483-95. doi:10.1084/jem. 188.3.483

97. Pruzina S, Williams GT, Kaneva G, Davies SL, Martin-Lopez A, Bruggemann M, et al. Human monoclonal antibodies to HIV-1 gp140 from mice bearing YAC-based human immunoglobulin transloci. Protein Eng Des Sel (2011) 24(10):791-9. doi:10.1093/protein/gzr038

98. Ma B, Osborn MJ, Avis S, Ouisse LH, Menoret S, Anegon I, et al. Human antibody expression in transgenic rats: comparison of chimeric IgH loci with human $\mathrm{VH}, \mathrm{D}$ and $\mathrm{JH}$ but bearing different rat C-gene regions. J Immunol Methods (2013) 400-401:78-86. doi:10.1016/j.jim.2013.10.007

99. Ching KH, Collarini EJ, Abdiche YN, Bedinger D, Pedersen D, Izquierdo S, et al. Chickens with humanized immunoglobulin genes generate antibodies with high affinity and broad epitope coverage to conserved targets. MAbs (2017):1-10. doi:10.1080/19420862.2017.1386825

100. de Haard HJ, van Neer N, Reurs A, Hufton SE, Roovers RC, Henderikx P, et al. A large non-immunized human Fab fragment phage library that permits rapid isolation and kinetic analysis of high affinity antibodies. J Biol Chem (1999) 274(26):18218-30. doi:10.1074/jbc.274.26.18218

101. Lu D, Shen J, Vil MD, Zhang H, Jimenez X, Bohlen P, et al. Tailoring in vitro selection for a picomolar affinity human antibody directed against vascular endothelial growth factor receptor 2 for enhanced neutralizing activity. J Biol Chem (2003) 278(44):43496-507. doi:10.1074/jbc.M307742200

102. Frenzel A, Schirrmann T, Hust M. Phage display-derived human antibodies in clinical development and therapy. MAbs (2016) 8(7):1177-94. doi:10.108 $0 / 19420862.2016 .1212149$

103. Prassler J, Thiel S, Pracht C, Polzer A, Peters S, Bauer M, et al. HuCAL PLATINUM, a synthetic Fab library optimized for sequence diversity and superior performance in mammalian expression systems. J Mol Biol (2011) 413(1):261-78. doi:10.1016/j.jmb.2011.08.012

104. Hanes J, Pluckthun A. In vitro selection and evolution of functional proteins by using ribosome display. Proc Natl Acad Sci U S A (1997) 94(10):4937-42. doi:10.1073/pnas.94.10.4937

105. Francisco JA, Campbell R, Iverson BL, Georgiou G. Production and fluorescence-activated cell sorting of Escherichia coli expressing a functional antibody fragment on the external surface. Proc Natl Acad Sci U S A (1993) 90(22):10444-8. doi:10.1073/pnas.90.22.10444

106. Cherf GM, Cochran JR. Applications of yeast surface display for protein engineering. Methods Mol Biol (2015) 1319:155-75. doi:10.1007/978-14939-2748-7_8

107. Beerli RR, Bauer M, Buser RB, Gwerder M, Muntwiler S, Maurer P, et al. Isolation of human monoclonal antibodies by mammalian cell display. Proc Natl Acad Sci U S A (2008) 105(38):14336-41. doi:10.1073/pnas.0805942105

108. Boder ET, Midelfort KS, Wittrup KD. Directed evolution of antibody fragments with monovalent femtomolar antigen-binding affinity. Proc Natl Acad Sci U S A (2000) 97(20):10701-5. doi:10.1073/pnas.170297297

109. Doerner A, Rhiel L, Zielonka S, Kolmar H. Therapeutic antibody engineering by high efficiency cell screening. FEBS Lett (2014) 588(2):278-87. doi:10.1016/j.febslet.2013.11.025 
110. Jacobs SA, Wu SJ, Feng Y, Bethea D, O’Neil KT. Cross-interaction chromatography: a rapid method to identify highly soluble monoclonal antibody candidates. Pharm Res (2010) 27(1):65-71. doi:10.1007/s11095-009-0007-z

111. Chennamsetty N, Voynov V, Kayser V, Helk B, Trout BL. Design of therapeutic proteins with enhanced stability. Proc Natl Acad Sci U S A (2009) 106(29):11937-42. doi:10.1073/pnas.0904191106

112. Chiu ML, Gilliland GL. Engineering antibody therapeutics. Curr Opin Struct Biol (2016) 38:163-73. doi:10.1016/j.sbi.2016.07.012

113. Shields RL, Namenuk AK, Hong K, Meng YG, Rae J, Briggs J, et al. High resolution mapping of the binding site on human IgG1 for Fc gamma RI, Fc gamma RII, Fc gamma RIII, and FcRn and design of IgG1 variants with improved binding to the Fc gamma R. J Biol Chem (2001) 276(9):6591-604. doi:10.1074/jbc.M009483200

114. Lazar GA, Dang W, Karki S, Vafa O, Peng JS, Hyun L, et al. Engineered antibody Fc variants with enhanced effector function. Proc Natl Acad Sci U S A (2006) 103(11):4005-10. doi:10.1073/pnas. 0508123103

115. Koerner SP, Andre MC, Leibold JS, Kousis PC, Kubler A, Pal M, et al. An Fc-optimized CD133 antibody for induction of NK cell reactivity against myeloid leukemia. Leukemia (2017) 31(2):459-69. doi:10.1038/leu.2016.194

116. Bruckheimer EM, Fazenbaker CA, Gallagher S, Mulgrew K, Fuhrmann S, Coffman KT, et al. Antibody-dependent cell-mediated cytotoxicity effector-enhanced EphA2 agonist monoclonal antibody demonstrates potent activity against human tumors. Neoplasia (2009) 11(6):509-17, 502 following 517. doi:10.1593/neo.81578

117. Liu Z, Gunasekaran K, Wang W, Razinkov V, Sekirov L, Leng E, et al. Asymmetrical Fc engineering greatly enhances antibody-dependent cellular cytotoxicity (ADCC) effector function and stability of the modified antibodies. J Biol Chem (2014) 289(6):3571-90. doi:10.1074/jbc.M113.513366

118. Watkins JD, Allan B. Fc Region Variants. (2004). Patent application: PCT/ US2004/005112.

119. Stavenhagen JB, Gorlatov S, Tuaillon N, Rankin CT, Li H, Burke S, et al. Fc optimization of therapeutic antibodies enhances their ability to kill tumor cells in vitro and controls tumor expansion in vivo via low-affinity activating Fcgamma receptors. Cancer Res (2007) 67(18):8882-90. doi:10.1158/00085472.CAN-07-0696

120. Richards JO, Karki S, Lazar GA, Chen H, Dang W, Desjarlais JR. Optimization of antibody binding to FcgammaRIIa enhances macrophage phagocytosis of tumor cells. Mol Cancer Ther (2008) 7(8):2517-27. doi:10.1158/1535-7163. MCT-08-0201

121. Idusogie EE, Wong PY, Presta LG, Gazzano-Santoro H, Totpal K, Ultsch M, et al. Engineered antibodies with increased activity to recruit complement. J Immunol (2001) 166(4):2571-5. doi:10.4049/jimmunol.166.4.2571

122. Davis PM, Abraham R, Xu L, Nadler SG, Suchard SJ. Abatacept binds to the Fc receptor CD64 but does not mediate complement-dependent cytotoxicity or antibody-dependent cellular cytotoxicity. J Rheumatol (2007) 34(11):2204-10.

123. McEarchern JA, Oflazoglu E, Francisco L, McDonagh CF, Gordon KA, Stone I, et al. Engineered anti-CD70 antibody with multiple effector functions exhibits in vitro and in vivo antitumor activities. Blood (2007) 109(3):1185-92. doi:10.1182/blood-2006-07-034017

124. Dall'Acqua WF, Kiener PA, Wu H. Properties of human IgG1s engineered for enhanced binding to the neonatal Fc receptor (FcRn). J Biol Chem (2006) 281(33):23514-24. doi:10.1074/jbc.M604292200

125. Leoh LS, Daniels-Wells TR, Martinez-Maza O, Penichet ML. Insights into the effector functions of human IgG3 in the context of an antibody targeting transferrin receptor 1. Mol Immunol (2015) 67(2 Pt B):407-15. doi:10.1016/j. molimm.2015.07.001

126. Hutchins JT, Kull FC Jr, Bynum J, Knick VC, Thurmond LM, Ray P. Improved biodistribution, tumor targeting, and reduced immunogenicity in mice with a gamma 4 variant of Campath-1H. Proc Natl Acad Sci U S A (1995) 92(26):11980-4. doi:10.1073/pnas.92.26.11980

127. Monnet C, Jorieux S, Urbain R, Fournier N, Bouayadi K, De Romeuf C, et al. Selection of IgG variants with increased FcRn binding using random and directed mutagenesis: impact on effector functions. Front Immunol (2015) 6:39. doi:10.3389/fimmu.2015.00039

128. Lee CH, Romain G, Yan W, Watanabe M, Charab W, Todorova B, et al. IgG Fc domains that bind $\mathrm{Clq}$ but not effector Fcgamma receptors delineate the importance of complement-mediated effector functions. Nat Immunol (2017) 18(8):889-98. doi:10.1038/ni.3770
129. Idusogie EE, Presta LG, Gazzano-Santoro H, Totpal K, Wong PY, Ultsch M, et al. Mapping of the $\mathrm{Clq}$ binding site on rituxan, a chimeric antibody with a human IgG1 Fc. J Immunol (2000) 164(8):4178-84. doi:10.4049/ jimmunol.164.8.4178

130. Hinton PR, Xiong JM, Johlfs MG, Tang MT, Keller S, Tsurushita N. An engineered human IgG1 antibody with longer serum half-life. J Immunol (2006) 176(1):346-56. doi:10.4049/jimmunol.176.1.346

131. Petkova SB, Akilesh S, Sproule TJ, Christianson GJ, Al Khabbaz H, Brown AC, et al. Enhanced half-life of genetically engineered human IgG1 antibodies in a humanized FcRn mouse model: potential application in humorally mediated autoimmune disease. Int Immunol (2006) 18(12):1759-69. doi:10.1093/ intimm/dxl110

132. Yeung YA, Leabman MK, Marvin JS, Qiu J, Adams CW, Lien S, et al. Engineering human IgG1 affinity to human neonatal Fc receptor: impact of affinity improvement on pharmacokinetics in primates. J Immunol (2009) 182(12):7663-71. doi:10.4049/jimmunol.0804182

133. Zalevsky J, Chamberlain AK, Horton HM, Karki S, Leung IW, Sproule TJ, et al. Enhanced antibody half-life improves in vivo activity. Nat Biotechnol (2010) 28(2):157-9. doi:10.1038/nbt.1601

134. Monnet C, Jorieux S, Souyris N, Zaki O, Jacquet A, Fournier N, et al. Combined glyco- and protein-Fc engineering simultaneously enhance cytotoxicity and half-life of a therapeutic antibody. MAbs (2014) 6(2):422-36. doi:10.4161/mabs.27854

135. Stapleton NM, Andersen JT, Stemerding AM, Bjarnarson SP, Verheul RC, Gerritsen J, et al. Competition for FcRn-mediated transport gives rise to short half-life of human IgG3 and offers therapeutic potential. Nat Commun (2011) 2:599. doi:10.1038/ncomms1608

136. Datta-Mannan A, Witcher DR, Tang Y, Watkins J, Jiang W, Wroblewski VJ. Humanized IgG1 variants with differential binding properties to the neonatal $\mathrm{Fc}$ receptor: relationship to pharmacokinetics in mice and primates. Drug Metab Dispos (2007) 35(1):86-94. doi:10.1124/dmd.106. 011734

137. Murphy K, Janeway CA, Travers P, Walport M. Chapter 10: The humoral immune response. 8th ed. Janeway's Immunobiology. New York: Garland Science (2012). p. 387-428.

138. Redman JM, Hill EM, AlDeghaither D, Weiner LM. Mechanisms of action of therapeutic antibodies for cancer. Mol Immunol (2015) 67(2 Pt A):28-45. doi:10.1016/j.molimm.2015.04.002

139. Suzuki M, Kato C, Kato A. Therapeutic antibodies: their mechanisms of action and the pathological findings they induce in toxicity studies. J Toxicol Pathol (2015) 28(3):133-9. doi:10.1293/tox.2015-0031

140. Vidarsson G, Dekkers G, Rispens T. IgG subclasses and allotypes: from structure to effector functions. Front Immunol (2014) 5:520. doi:10.3389/ fimmu.2014.00520

141. Cartron G, Dacheux L, Salles G, Solal-Celigny P, Bardos P, Colombat P, et al. Therapeutic activity of humanized anti-CD20 monoclonal antibody and polymorphism in IgG Fc receptor FcgammaRIIIa gene. Blood (2002) 99(3):754-8. doi:10.1182/blood.V99.3.754

142. Weng WK, Levy R. Two immunoglobulin G fragment $\mathrm{C}$ receptor polymorphisms independently predict response to rituximab in patients with follicular lymphoma. J Clin Oncol (2003) 21(21):3940-7. doi:10.1200/JCO. 2003.05.013

143. Musolino A, Naldi N, Bortesi B, Pezzuolo D, Capelletti M, Missale G, et al. Immunoglobulin $\mathrm{G}$ fragment $\mathrm{C}$ receptor polymorphisms and clinical efficacy of trastuzumab-based therapy in patients with HER-2/neu-positive metastatic breast cancer. J Clin Oncol (2008) 26(11):1789-96. doi:10.1200/ JCO.2007.14.8957

144. Bibeau F, Lopez-Crapez E, Di Fiore F, Thezenas S, Ychou M, Blanchard F, et al. Impact of Fc \{gamma\}RIIa-Fc \{gamma\}RIIIa polymorphisms and KRAS mutations on the clinical outcome of patients with metastatic colorectal cancer treated with cetuximab plus irinotecan. J Clin Oncol (2009) 27(7):1122-9. doi:10.1200/JCO.2008.18.0463

145. Braster R, O’Toole T, van Egmond M. Myeloid cells as effector cells for monoclonal antibody therapy of cancer. Methods (2014) 65(1):28-37. doi:10.1016/j.ymeth.2013.06.020

146. Wang C, Thudium KB, Han M, Wang XT, Huang H, Feingersh D, et al. In vitro characterization of the anti-PD-1 antibody nivolumab, BMS-936558, and in vivo toxicology in non-human primates. Cancer Immunol Res (2014) 2(9):846-56. doi:10.1158/2326-6066.CIR-14-0040 
147. van der Kolk LE, Grillo-Lopez AJ, Baars JW, Hack CE, van Oers MH. Complement activation plays a key role in the side-effects of rituximab treatment. Br J Haematol (2001) 115(4):807-11. doi:10.1046/j.1365-2141. 2001.03166.x

148. Wang SY, Racila E, Taylor RP, Weiner GJ. NK-cell activation and antibody-dependent cellular cytotoxicity induced by rituximab-coated target cells is inhibited by the C3b component of complement. Blood (2008) 111(3):1456-63. doi:10.1182/blood-2007-02-074716

149. Arnold JN, Wormald MR, Sim RB, Rudd PM, Dwek RA. The impact of glycosylation on the biological function and structure of human immunoglobulins. Annu Rev Immunol (2007) 25:21-50. doi:10.1146/annurev. immunol.25.022106.141702

150. Epp A, Sullivan KC, Herr AB, Strait RT. Immunoglobulin glycosylation effects in allergy and immunity. Curr Allergy Asthma Rep (2016) 16(11):79. doi:10.1007/s11882-016-0658-x

151. Bolt S, Routledge E, Lloyd I, Chatenoud L, Pope H, Gorman SD, et al. The generation of a humanized, non-mitogenic CD3 monoclonal antibody which retains in vitro immunosuppressive properties. Eur J Immunol (1993) 23(2):403-11. doi:10.1002/eji.1830230216

152. Yu X, Marshall MJE, Cragg MS, Crispin M. Improving antibody-based cancer therapeutics through glycan engineering. BioDrugs (2017) 31(3):151-66. doi:10.1007/s40259-017-0223-8

153. Weiskopf K, Weissman IL. Macrophages are critical effectors of antibody therapies for cancer. MAbs (2015) 7(2):303-10. doi:10.1080/19420862. 2015.1011450

154. Shinkawa T, Nakamura K, Yamane N, Shoji-Hosaka E, Kanda Y, Sakurada M, et al. The absence of fucose but not the presence of galactose or bisecting $\mathrm{N}$-acetylglucosamine of human IgG1 complex-type oligosaccharides shows the critical role of enhancing antibody-dependent cellular cytotoxicity. J Biol Chem (2003) 278(5):3466-73. doi:10.1074/jbc.M210665200

155. Kanda Y, Yamane-Ohnuki N, Sakai N, Yamano K, Nakano R, Inoue M, et al. Comparison of cell lines for stable production of fucose-negative antibodies with enhanced ADCC. Biotechnol Bioeng (2006) 94(4):680-8. doi:10.1002/ bit. 20880

156. Yamane-Ohnuki N, Kinoshita S, Inoue-Urakubo M, Kusunoki M, Iida S, Nakano R, et al. Establishment of FUT8 knockout Chinese hamster ovary cells: an ideal host cell line for producing completely defucosylated antibodies with enhanced antibody-dependent cellular cytotoxicity. Biotechnol Bioeng (2004) 87(5):614-22. doi:10.1002/bit.20151

157. Shields RL, Lai J, Keck R, O'Connell LY, Hong K, Meng YG, et al. Lack of fucose on human IgG1 N-linked oligosaccharide improves binding to human Fcgamma RIII and antibody-dependent cellular toxicity. J Biol Chem (2002) 277(30):26733-40. doi:10.1074/jbc.M202069200

158. Herbst R, Wang Y, Gallagher S, Mittereder N, Kuta E, Damschroder M, et al. B-cell depletion in vitro and in vivo with an afucosylated anti-CD19 antibody. J Pharmacol Exp Ther (2010) 335(1):213-22. doi:10.1124/jpet.110.168062

159. Mori K, Kuni-Kamochi R, Yamane-Ohnuki N, Wakitani M, Yamano K, Imai $\mathrm{H}$, et al. Engineering Chinese hamster ovary cells to maximize effector function of produced antibodies using FUT8 siRNA. Biotechnol Bioeng (2004) 88(7):901-8. doi:10.1002/bit.20326

160. Gerdes CA, Nicolini VG, Herter S, van Puijenbroek E, Lang S, Roemmele M, et al. GA201 (RG7160): a novel, humanized, glycoengineered anti-EGFR antibody with enhanced ADCC and superior in vivo efficacy compared with cetuximab. Clin Cancer Res (2013) 19(5):1126-38. doi:10.1158/1078-0432.CCR-12-0989

161. Umana P, Jean-Mairet J, Moudry R, Amstutz H, Bailey JE. Engineered glycoforms of an antineuroblastoma IgG1 with optimized antibody-dependent cellular cytotoxic activity. Nat Biotechnol (1999) 17(2):176-80. doi:10.1038/6179

162. Evans JB, Syed BA. From the analyst's couch: next-generation antibodies. Nat Rev Drug Discov (2014) 13(6):413-4. doi:10.1038/nrd4255
163. van BerkelPH, GerritsenJ, van VoskuilenE,PerdokG, VinkT,van de WinkelJG, et al. Rapid production of recombinant human IgG With improved ADCC effector function in a transient expression system. Biotechnol Bioeng (2010) 105(2):350-7. doi:10.1002/bit.22535

164. Ferrara C, Brunker P, Suter T, Moser S, Puntener U, Umana P. Modulation of therapeutic antibody effector functions by glycosylation engineering: influence of Golgi enzyme localization domain and co-expression of heterologous beta1, 4-N-acetylglucosaminyltransferase III and Golgi alpha-mannosidase II. Biotechnol Bioeng (2006) 93(5):851-61. doi:10.1002/bit.20777

165. Calow J, Behrens AJ, Mader S, Bockau U, Struwe WB, Harvey DJ, et al. Antibody production using a ciliate generates unusual antibody glycoforms displaying enhanced cell-killing activity. MAbs (2016) 8(8):1498-511. doi:10 $.1080 / 19420862.2016 .1228504$

166. Cox KM, Sterling JD, Regan JT, Gasdaska JR, Frantz KK, Peele CG, et al. Glycan optimization of a human monoclonal antibody in the aquatic plant Lemna minor. Nat Biotechnol (2006) 24(12):1591-7. doi:10.1038/ nbt1260

167. Li H, Sethuraman N, Stadheim TA, Zha D, Prinz B, Ballew N, et al. Optimization of humanized IgGs in glycoengineered Pichia pastoris. Nat Biotechnol (2006) 24(2):210-5. doi:10.1038/nbt1178

168. Sachdeva M, Dhingra S. Obinutuzumab: a FDA approved monoclonal antibody in the treatment of untreated chronic lymphocytic leukemia. Int J Appl Basic Med Res (2015) 5(1):54-7. doi:10.4103/2229-516X.149245

169. Fala L. Gazyva (obinutuzumab) approved for patients with rituximab-refractory follicular lymphoma. Am Health Drug Benefits (2017) 10:54-6.

170. Ober RJ, Martinez C, Lai X, Zhou J, Ward ES. Exocytosis of IgG as mediated by the receptor, FcRn: an analysis at the single-molecule level. Proc Natl Acad Sci U S A (2004) 101(30):11076-81. doi:10.1073/pnas.0402970101

171. Ober RJ, Martinez C, Vaccaro C, Zhou J, Ward ES. Visualizing the site and dynamics of IgG salvage by the MHC class I-related receptor, FcRn. J Immunol (2004) 172(4):2021-9. doi:10.4049/jimmunol.172.4.2021

172. Prabhat P, Gan Z, Chao J, Ram S, Vaccaro C, Gibbons S, et al. Elucidation of intracellular recycling pathways leading to exocytosis of the $\mathrm{Fc}$ receptor, FcRn, by using multifocal plane microscopy. Proc Natl Acad Sci U S A (2007) 104(14):5889-94. doi:10.1073/pnas.0700337104

173. Firan M, Bawdon R, Radu C, Ober RJ, Eaken D, Antohe F, et al. The MHC class I-related receptor, FcRn, plays an essential role in the maternofetal transfer of gamma-globulin in humans. Int Immunol (2001) 13(8):993-1002. doi:10.1093/intimm/13.8.993

174. Robbie GJ, Criste R, Dall'acqua WF, Jensen K, Patel NK, Losonsky GA, et al. A novel investigational Fc-modified humanized monoclonal antibody, motavizumab-YTE, has an extended half-life in healthy adults. Antimicrob Agents Chemother (2013) 57(12):6147-53. doi:10.1128/AAC.01285-13

175. Heineke MH, van Egmond M. Immunoglobulin A: magic bullet or Trojan horse? Eur J Clin Invest (2017) 47(2):184-92. doi:10.1111/eci.12716

176. Leoh LS, Daniels-Wells TR, Penichet ML. IgE immunotherapy against cancer. Curr Top Microbiol Immunol (2015) 388:109-49. doi:10.1007/978-3-31913725-4_6

Conflict of Interest Statement: MP is a shareholder of Klyss Biotech, Inc. The Regents of the University of California are in discussions with Klyss Biotech, Inc. to license MP's technology to this biotech company. The other authors declare that the research was conducted in the absence of any commercial or financial relationships that could be construed as a potential conflict of interest.

Copyright $\odot 2018$ Almagro, Daniels-Wells, Perez-Tapia, and Penichet. This is an open-access article distributed under the terms of the Creative Commons Attribution License (CC BY). The use, distribution or reproduction in other forums is permitted, provided the original author(s) or licensor are credited and that the original publication in this journal is cited, in accordance with accepted academic practice. No use, distribution or reproduction is permitted which does not comply with these terms. 